\title{
Sensitivity of aerosol concentrations and cloud properties to nucleation and secondary organic distribution in ECHAM5-HAM global circulation model
}

\author{
R. Makkonen ${ }^{1}$, A. Asmi ${ }^{1}$, H. Korhonen ${ }^{2}$, H. Kokkola ${ }^{3}$, S. Järvenoja ${ }^{4}{ }^{\dagger}$, P. Räisänen ${ }^{4}$, K. E. J. Lehtinen ${ }^{2,5}$, \\ A. Laaksonen ${ }^{2,5}$, V.-M. Kerminen ${ }^{4}$, H. Järvinen ${ }^{4}$, U. Lohmann ${ }^{6}$, R. Bennartz ${ }^{7}$, J. Feichter ${ }^{3}$, and M. Kulmala ${ }^{1}$ \\ ${ }^{1}$ Department of Physics, University of Helsinki, 00014, Helsinki, Finland \\ ${ }^{2}$ Department of Physics, University of Kuopio, 70211, Kuopio, Finland \\ ${ }^{3}$ Max Planck Institute for Meteorology, 20146, Hamburg, Germany \\ ${ }^{4}$ Finnish Meteorological Institute, 00101, Helsinki, Finland \\ ${ }^{5}$ Finnish Meteorological Institute, 70211, Kuopio, Finland \\ ${ }^{6}$ Institute of Atmospheric and Climate Science, ETH Zurich, 8092, Zurich, Switzerland \\ ${ }^{7}$ Department of Atmospheric and Oceanic Sciences, University of Wisconsin, Madison, Wisconsin, USA \\ $\dagger$ deceased, October 2007
}

Received: 25 April 2008 - Published in Atmos. Chem. Phys. Discuss.: 6 June 2008

Revised: 28 January 2009 - Accepted: 28 January 2009 - Published: 9 March 2009

\begin{abstract}
The global aerosol-climate model ECHAM5HAM was modified to improve the representation of new particle formation in the boundary layer. Activation-type nucleation mechanism was introduced to produce observed nucleation rates in the lower troposphere. A simple and computationally efficient model for biogenic secondary organic aerosol (BSOA) formation was implemented. Here we study the sensitivity of the aerosol and cloud droplet number concentrations (CDNC) to these additions. Activationtype nucleation significantly increases aerosol number concentrations in the boundary layer. Increased particle number concentrations have a significant effect also on cloud droplet number concentrations and therefore on cloud properties. We performed calculations with activation nucleation coefficient values of $2 \times 10^{-7} \mathrm{~s}^{-1}, 2 \times 10^{-6} \mathrm{~s}^{-1}$ and $2 \times 10^{-5} \mathrm{~s}^{-1}$ to evaluate the sensitivity to this parameter. For BSOA we have used yields of $0.025,0.07$ and 0.15 to estimate the amount of monoterpene oxidation products available for condensation. The hybrid BSOA formation scheme induces large regional changes to size distribution of organic carbon, and therefore affects particle optical properties and cloud droplet number concentrations locally. Although activation-type nu-
\end{abstract}

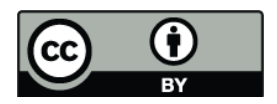

Correspondence to: R. Makkonen (risto.makkonen@helsinki.fi) cleation improves modeled aerosol number concentrations in the boundary layer, the use of a global activation coefficient generally leads to overestimation of aerosol number. Overestimation can also arise from underestimation of primary emissions.

\section{Introduction}

Atmospheric aerosols are an important, yet poorly understood, part of the climate system, with largest uncertainties being associated with aerosol-cloud interactions (Lohmann and Feichter, 2005; Penner et al., 2006; Forster et al., 2007; Baker and Peter, 2008). The various effects of aerosols on climate can only be addressed with the help of regional and global climate models. Most current global climate models include the main aerosol types but have a rather simplistic treatment of the aerosol size distribution and associated microphysical processes (e.g. Chen et al., 2007; Jones et al., 2007; Shindell et al., 2007). This is a serious shortcoming that needs, and probably will, be improved in next-generation climate models (Ghan and Schwartz, 2007; Textor et al., 2007).

The aerosol climate model ECHAM5-HAM (Stier et al., 2005) has a relatively detailed description of aerosol microphysics, making it a promising tool for studying

Published by Copernicus Publications on behalf of the European Geosciences Union. 
aerosol-climate interactions. However, like practically all other large-scale models, ECHAM5-HAM has a very crude presentation of atmospheric new particle formation and secondary organic aerosol formation. In this study we will investigate how simulated aerosol and cloud droplet number concentrations depend on the implementation of these two processes in ECHAM5-HAM.

Both observations and model studies have shown that atmospheric new particle formation is a significant source of aerosols in the global troposphere (e.g. Kulmala et al., 2004; Spracklen et al., 2006). At present, parameterizations for modeling purposes are available for binary watersulphuric acid nucleation (e.g. Vehkamäki et al., 2002), ternary water-sulphuric acid-ammonia nucleation (Napari et al., 2002; Merikanto et al., 2007), ion-induced nucleation involving sulphuric acid and water (Modgil et al., 2005), combined ion-induced and neutral formation of sulfate aerosols (Kazil and Lovejoy, 2007), and for so-called "activationtype" and "kinetic-type" nucleation involving sulphuric acid as a driver (Kulmala et al., 2006; Riipinen et al., 2007; Kuang et al., 2008). Most large-scale models include only binary water-sulphuric acid nucleation, which leads to a serious underestimation of new particle formation in continental boundary layers (e.g. Stier et al., 2005; Lucas and Arimoto, 2006). The existing ion-induced nucleation mechanisms seem to suffer from the same problem (Kazil et al., 2006; Lucas and Arimoto, 2006). Ternary water-sulphuric acid-ammonia nucleation appears to perform reasonably well in certain urban centers (e.g. Gaydos et al., 2005), but has a tendency to produce too many particles throughout most of the global troposphere (Lucas and Arimoto, 2006). The activation-type nucleation, while not yet detailed enough to take into account all the influencing factors (e.g. Sihto et al., 2006; Riipinen et al., 2007), appears to be a good candidate for describing boundary-layer nucleation in global modeling frameworks (Spracklen et al., 2006). Large-scale models cannot usually deal with small clusters formed by nucleation, so it is desirable to combine the used nucleation parameterization with another parameterization able to deal with the initial growth of nucleated clusters to a few nanometers (Kerminen and Kulmala, 2002; Kerminen et al., 2004; McMurry et al., 2005; Lehtinen et al., 2007).

Secondary organic aerosol (SOA) constitutes a substantial fraction of submicron particulate matter in the global troposphere (Tsigaridis et al., 2003; Lack et al., 2004; Fuzzi et al., 2006), in addition to which it plays a central role in coupling atmospheric new particle formation and production of new cloud condensation nuclei (Lihavainen et al., 2003; Kerminen et al., 2005; Laaksonen et al., 2005; Tunved et al., 2006; Spracklen et al., 2008). Most of the atmospheric SOA is believed to originate from biogenic sources, even though also anthropogenic precursor compounds may constitute a significant contribution (Volkamer et al., 2006; de Gouw et al., 2008). Modeling SOA formation in the global atmosphere is subject to large uncertainties (Kanakidou et al., 2005). New schemes to simulate atmospheric SOA formation are being developed continuously (e.g. Griffin et al., 2005, Tulet et al., 2006; Pun and Seigneur, 2007; Liu and Zhang, 2008), yet only a few global models are able to simulate SOA formation explicitly (e.g. Chung and Seinfeld, 2002; Tsigaridis et al., 2003; Guillaume et al., 2007; Hoyle et al., 2007; Goto et al., 2008).

In this work, we will run ECHAM5-HAM with both binary water-sulphuric acid and activation-type nucleation schemes. Simulations with and without explicit treatment of SOA formation will be conducted. Our main objectives are to investigate how sensitive simulated aerosol and cloud droplet number concentrations are to the nucleation mechanism, and how important it is to simulate the distribution of SOA over the particle size spectrum explicitly as compared with treating SOA as part of the primary organic aerosol emissions.

\section{Methods}

\subsection{ECHAM5-HAM general circulation model}

We use the ECHAM5 general circulation model (GCM) with the HAM aerosol model (Stier et al., 2005) for global simulations. AEROCOM emission inventories for year 2000 are used for sulphur compounds, black carbon and organic matter. Emissions of mineral dust, sea salt and oceanic dimethyl sulfide (DMS) are calculated online. Emissions are considered as primary emissions, except for sulphur compounds, for which $97.5 \%$ of the emitted mass is in the form of sulphur dioxide. The remaining $2.5 \%$ is modeled as a primary emission to estimate subgrid-scale nucleation. The aerosol module HAM includes a chemistry model that treats DMS, sulphur dioxide and sulfate.

HAM uses M7 microphysics model to describe aerosol dynamics (Vignati et al., 2004). M7 includes double-moment modal microphysics scheme, where the population is composed of seven log-normal distributions. M7 describes the aerosol distribution with one soluble nucleation mode, and both soluble and insoluble Aitken, accumulation and coarse modes. Standard deviations of the modes are kept constant (2.00 for coarse modes, 1.59 for others) and thus advection of only number and mass concentrations is calculated. The upper limits for particle radius are $5 \mathrm{~nm}, 50 \mathrm{~nm}$ and $0.5 \mu \mathrm{m}$ for nucleation, Aitken and accumulation mode, respectively. The processes in M7 include nucleation, coagulation and condensation. More details on size ranges and dynamics are available in Stier et al. (2005) and Vignati et al. (2004). The most important factor of HAM/M7 regarding this study is the fact that particles have the possibility to grow from one mode to another by condensation, thus a physical connection between nucleation mode (newly formed particles) and larger modes (potential cloud condensation nuclei $(\mathrm{CCN})$ ) can be made. 
We have implemented a new nucleation mechanism and the hybrid BSOA formation scheme in M7. Nucleation formulations were done by changing the nucleation subroutines, keeping the dynamics of M7 otherwise as in ECHAM5HAM. For the BSOA condensation experiment, three new tracers were introduced to include organic matter in soluble nucleation and insoluble accumulation and coarse modes. These modifications had only a minor effect on model computational efficiency.

All experiments were conducted with T42 horizontal resolution, which corresponds to approximately $2.8^{\circ} \times 2.8^{\circ}$ grid. Vertically, 19 hybrid levels were used, extending up to $10 \mathrm{hPa}$. A time step of $30 \mathrm{~min}$ was used for most calculations including chemistry and aerosol microphysics. For each experiment, we performed a model spin-up for six months to initialize aerosol fields, and continued with a one-year simulation for analysis. To estimate inter-annual variations, one experiment was simulated for a five-year period. Resulting statistics are calculated from model output resolution of six hours.

\subsection{Cloud droplet activation scheme}

Modeled aerosol fields are used to calculate CDNC according to Lohmann et al. (2007). Aerosols are activated as cloud droplets according to Lin and Leaitch (1997) using

$$
Q_{\text {nucl }}=\max \left[\frac{1}{\Delta t}\left(0.1\left(\frac{N_{a} w}{w+\alpha N_{a}}\right)^{1.27}-N_{l, \text { old }}\right), 0\right],
$$

where $Q_{\text {nucl }}\left(\mathrm{m}^{-3} \mathrm{~s}^{-1}\right)$ is the cloud droplet nucleation rate, $N_{a}\left(\mathrm{~m}^{-3}\right)$ is the number concentration of the aerosol particles with wet radii $>0.035 \mu \mathrm{m}, w\left(\mathrm{~m} \mathrm{~s}^{-1}\right)$ is the vertical velocity, $\Delta t$ (s) is the time step, $N_{l, \text { old }}$ is the CDNC from the previous timestep and $\alpha=0.023 \mathrm{~cm}^{4} \mathrm{~s}^{-1}$. Vertical velocity is calculated from turbulent kinetic energy, convectively available potential energy and mean vertical velocity. The above parameterization is based on observational data. Because these observational data do not distinguish between soluble and insoluble aerosols, Lohmann et al. (2007) use all aerosols irrespectively of their mixing state for cloud droplet nucleation. However, the aerosol module HAM distinguishes soluble/mixed from insoluble particles. Thus we also conduct experiments assuming that only soluble fraction of particle population is activated. The lower limit of CDNC is set to $40 \mathrm{~cm}^{-3}$. We did not investigate any potential impact on ice clouds.

\subsection{New particle formation due to nucleation in atmosphere}

Modeling new particle formation is not an easy process to consider in a modal model. Freshly nucleated particles can have sub-nanometer sizes. These particles grow by condensation, but still remain inside the nucleation mode until they reach a radius of $\sim 5 \mathrm{~nm}$. A single lognormal distribution can not keep track of aged nucleation mode particles and freshly formed particles, therefore information of the early growth of particles is lost. In this study, we use a formulation by Kerminen et al. (2004) to estimate the formation rate of particles of $3 \mathrm{~nm}$ in size. This was done using the equation (Kerminen and Kulmala, 2002; Kerminen et al., 2004):

$J_{3 n m}=J_{\text {nuc }} \times \exp \left[\gamma \times\left(\frac{1}{3.0 n m}-\frac{1}{d_{n u c}}\right) \times \frac{C S^{\prime}}{G R}\right]$,

where $J_{\text {nuc }}\left(\mathrm{cm}^{-3} \mathrm{~s}^{-1}\right)$ is the nucleation rate of particles of size $d_{\text {nuc }}(\mathrm{nm}), J_{3 \mathrm{~nm}}\left(\mathrm{~cm}^{-3} \mathrm{~s}^{-1}\right)$ is the formation rate of $3 \mathrm{~nm}$ size particles, $\gamma\left(\mathrm{nm}^{2} \mathrm{~m}^{2} \mathrm{~h}^{-1}\right)$ is a function of ambient conditions, properties of the nuclei and pre-existing particle population and $G R\left(\mathrm{~nm} \mathrm{hour}^{-1}\right)$ is the particle growth rate. $C S$, $\left(\mathrm{m}^{-2}\right)$ is proportional to the condensation sink and can be calculated from

$$
C S^{\prime}=\frac{1}{2} \sum_{j} \frac{d_{p, j} N_{j}\left(1+K n_{j}\right)}{1+0.377 K n_{j}+1.33 K n_{j}\left(1+K n_{j}\right)},
$$

where $d_{p, j}(\mathrm{~nm})$ is the particle diameter in size bin $j, K n_{j}$ is the Knudsen number and $N_{j}\left(\mathrm{~cm}^{-3}\right)$ is their number concentration. Two assumptions were made in calculating the growth rate of sub-3-nm particles $(G R)$ in Eq. (2). First, only sulphuric acid was assumed to condense on particles smaller than $3 \mathrm{~nm}$, and second, the condensational flux of sulphuric acid can be described with the free molecular regime formulation. With these assumptions, we obtain (Kerminen and Kulmala, 2002):

$$
G R \approx \frac{3.0 \times 10^{-9}}{\rho_{\mathrm{nuc}}} \sum_{i} \bar{c}_{i} M_{i} C_{i},
$$

where $G R$ is in nm hour ${ }^{-1}, \rho_{\text {nuc }}\left(\mathrm{kg} \mathrm{m}^{-3}\right)$ is the density of the nuclei, $\bar{c}_{i}\left(\mathrm{~m} \mathrm{~s}^{-1}\right)$ is the average molecular speed of sulphuric acid, $M_{i}\left(\mathrm{~g} \mathrm{~mol}^{-1}\right)$ is its molecular weight and $C_{i}\left(\mathrm{~cm}^{-3}\right)$ is its vapor concentration. The term $3.0 \times 10^{-9}$ contains all the constants and conversion factors between the units. Our assumptions may lead to an underestimation of the value of $G R$ below $3 \mathrm{~nm}$. As a result, for a given nucleation rate $\left(J_{\text {nuc }}\right)$ and size $\left(d_{\text {nuc }}\right)$, a conservative estimate of $J_{3 \mathrm{~nm}}$ will be obtained.

In activation-type nucleation, sulphuric acid molecules "activate" pre-existing clusters for further growth. For this type of nucleation, the actual nucleation rate $J_{\text {nuc }}$ can be postulated simply as (Kulmala et al., 2006)

$J_{n u c}=A \times\left[\mathrm{H}_{2} \mathrm{SO}_{4}\right]$

The activation coefficient $A$ contains information about the concentration of the background clusters and dynamics between them and sulphuric acid molecules. The coefficient $A$ varies from one location to another, and for example in Hyytiälä conditions it is reported to be on the order of $10^{-6} \mathrm{~s}^{-1}$ (Sihto et al., 2006; Riipinen et al., 2007). Few measurements are available that can provide information about the spatial distribution of the activation coefficient, so we have to assume a constant coefficient $A$ for the whole atmosphere. In this study, we assumed a value of $2 \times 10^{-6} \mathrm{~s}^{-1}$, but 
we tested the sensitivity of aerosol and cloud droplet concentrations to this coefficient. We also assumed that the radius $d_{\text {nuc }}$ of activated clusters is $1 \mathrm{~nm}$.

Binary nucleation in the ECHAM5-HAM is based on Vehkamäki et al. (2002) parameterization of homogenous water-sulphuric acid nucleation. In order to select a realistic implementation of activation-type nucleation together with binary nucleation, the following model configurations were considered:

(1) activation-type nucleation as a simultaneous process with binary nucleation, where both nucleation mechanisms used the same sulphuric acid concentration to estimate $J_{3 \mathrm{~nm}}$, and these formation rates were summed up to obtain the apparent formation rate;

(2) as above, but with the activation nucleation considered only below altitudes of $800 \mathrm{hPa}$;

(3) as (1), but using only the higher $J_{3 \mathrm{~nm}}$ of the two methods to calculate the apparent formation rate;

(4) assuming that activation nucleation happens first, then recalculating the remaining sulphuric acid concentration and from that the binary nucleation rate;

(5) using binary nucleation only, without using Eq. (2).

Method (2) would assume that activation-type nucleation only occurs in the boundary layer. Methods (1), (3) and (4) produce quite similar results in lower troposphere, since binary nucleation rates at these altitudes are significantly lower than activation-type nucleation rates. Effect of activationtype nucleation on cloud droplets in methods (1-4) is fairly similar, since most cloud droplets occur below $800 \mathrm{hPa}$. Results presented in this paper were done with methods (1) and (5). Method (5) corresponds to the original ECHAM5-HAM nucleation scheme.

\subsection{Hybrid BSOA formation scheme}

The formation of biogenic secondary organic aerosol involves a complicated set of processes. In atmospheric BSOA formation, the following steps can be identified: (1) emissions of precursor compounds to the atmosphere, (2) gasphase chemistry responsible for the conversion of precursors to less volatile organic compounds, (3) partitioning of these compounds between gas and aerosol phases, (4) aerosolphase chemistry, and (5) chemical reactions taking place in cloud droplets.

In this work, BSOA precursor emissions are approximated by monoterpene emissions calculated using the Guenther et al. (1995) algorithm, as done in the original ECHAM5HAM. No isoprene or other biogenic precursors are taken into account, even though these compounds are likely to contribute to atmospheric BSOA (e.g. Bonn et al., 2004; Henze and Seinfeld, 2006). Our approach also neglects BSOA originating from marine emissions. This source could be globally important but is extremely poorly constrained at the moment (Roelofs, 2008; Spracklen et al., 2008b).
Although fully kinetic frameworks for simulating the chemistry and gas/particle partitioning of organic compounds have been developed (e.g. Camredon et al., 2007; Chan et al., 2007), their use in atmospheric SOA models is not yet feasible. Most large-scale models constructed so far simulate atmospheric SOA by using the so-called twoproduct approach, in which all SOA is described with one "low-volatile" and one "semi-volatile" model compound. The yields and partitioning coefficients of these model compounds are usually taken from smog chamber experiments. The existing models tend to underestimate the mass concentration of atmospheric SOA considerably, even up to $90 \%$ (e.g. Heald et al., 2005). The reasons for this underestimation are unclear but could be due to incorrect emission inventories, due to missing precursors compound, reaction pathways or reaction products, or due to chemistry taking place in aerosol particles or cloud droplets (e.g. Chen et al., 2007; Ervens and Kreidenweis, 2007; Ng et al., 2007; Robinson et al., 2007).

In the original ECHAM5-HAM model, SOA is treated as part of the primary emissions by assuming that $15 \%$ of the emitted monoterpenes produce SOA. Of this SOA, $65 \%$ is distributed evenly between the soluble Aitken and accumulation mode and the rest (35\%) is put into the insoluble Aitken mode. Here we take a more general approach, with no prescribed assumptions about the size distribution or solubility of the organic matter. We first assume that emitted monoterpenes produce SOA with a constant yield. This SOA is then distributed over the particle size spectrum in proportion to the condensation sink of each mode, as calculated from the modal parameter under ambient conditions. All the SOA is assumed to be formed at the grid point of emission within one model time step ( $30 \mathrm{~min})$.

Our hybrid approach would predict a correct SOA distribution if all of the SOA were made of very low-volatility compounds produced by rapid gas-phase reactions. In reality this is not the case. First of all, a large fraction of SOA is made of semi-volatile matter. The partitioning of such matter between the gas and aerosol phases depends on both temperature and properties of the pre-existing aerosol particle population (e.g. Svendby et al., 2008). Second, an unknown fraction of SOA is produced by chemical reactions taking place over hours or days. Our simplistic approach is therefore expected to result in errors in the vertical distribution, spatial extent and size distribution of the predicted BSOA. However, given the major computational costs associated with using more elaborate BSOA formation mechanisms, as well as the major uncertainties related to these mechanisms, we consider our hybrid approach justified in this study.

\section{Results}

The experiments done in this study are listed in Table 1. Experiment B serves as a base-case, since it uses standard 
Table 1. Experiment names, nucleation methods and BSOA method of different experiments. Experiment B is a reference simulation, since it is simulated with standard ECHAM5-HAM. Experiments B_SOLACT and AO_SOLACT assume cloud droplet activation of soluble aerosol modes only, others include cloud droplet activation of both soluble and insoluble modes.

\begin{tabular}{lll}
\hline Experiment & Nucleation method & BSOA method \\
\hline B & Binary & Standard ECHAM5-HAM \\
A0 & Activation $\left(\mathrm{A}=2 \times 10^{-7} \mathrm{~s}^{-1}\right)$ and Binary & Standard ECHAM5-HAM \\
A1 & Activation $\left(\mathrm{A}=2 \times 10^{-6} \mathrm{~s}^{-1}\right)$ and Binary & Standard ECHAM5-HAM \\
A2 & Activation $\left(\mathrm{A}=2 \times 10^{-5} \mathrm{~s}^{-1}\right)$ and Binary & Standard ECHAM5-HAM \\
AS1 & Activation $\left(\mathrm{A}=2 \times 10^{-6} \mathrm{~s}^{-1}\right)$ and Binary & Condensing BSOA (Yield 0.07) \\
AS2 & Activation $\left(\mathrm{A}=2 \times 10^{-6} \mathrm{~s}^{-1}\right)$ and Binary & Condensing BSOA (Yield 0.15) \\
S0 & Binary & Condensing BSOA (Yield 0.025) \\
S1 & Binary & Condensing BSOA (Yield 0.07) \\
S2 & Binary & Condensing BSOA (Yield 0.15) \\
B_SOLACT & Binary & Standard ECHAM5-HAM \\
A0_SOLACT & Activation $\left(\mathrm{A}=2 \times 10^{-7} \mathrm{~s}^{-1}\right)$ and Binary & Standard ECHAM5-HAM \\
\hline
\end{tabular}

ECHAM5-HAM binary nucleation and BSOA scheme. In experiments $\mathrm{A} 0, \mathrm{~A} 1$ and $\mathrm{A} 2$ only the nucleation mechanism is modified and in experiments S0, S1 and S2 only the BSOA scheme is changed. Experiments AS1 and AS2 describe new particle formation with both activation-type nucleation and hybrid BSOA formation scheme. Experiments B_SOLACT and A0_SOLACT are as B and A0, but cloud droplet activation is considered for soluble aerosol modes only.

3.1 Sensitivity of aerosol number distributions and particle formation rates to the choice of nucleation mechanism

Nucleation mode aerosols originate solely from atmospheric new-particle formation in ECHAM5-HAM. As a result, the number concentration of nucleation mode particles provides a good measure of the effect of nucleation on particle number concentration without ignoring their coagulation losses below detectable sizes. The number concentration of nucleation mode particles is not directly related to the nucleation rate but it provides a comparable measure for evaluating model results against aerosol measurements. Another factor of interest is the Aitken mode particle number concentration, as it is also somewhat controlled by growing nucleation mode particles and has the potential to have climate effects e.g. by acting as cloud condensation nuclei.

Figure 1 shows the annual average vertical profiles of nucleation mode number concentration and total number concentration without nucleation mode in experiments $\mathrm{B}, \mathrm{A} 0$, A1 and A2. Pure binary nucleation produces high nucleation mode number concentrations in the upper troposphere and lower stratosphere with a peak concentration around $200 \mathrm{hPa}$,

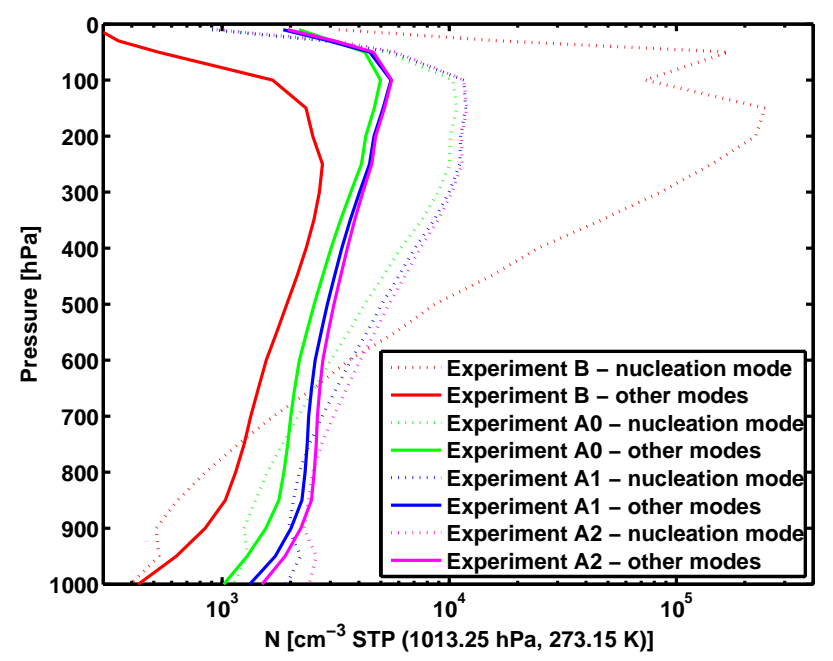

Fig. 1. Annual global averages of aerosol number concentrations as a function of altitude. Dotted line represents nucleation mode concentration and solid line the total number concentration neglecting nucleation mode.

which is the only region where modeled binary nucleation rates on average exceed activation nucleation rates. However, the concentrations of both nucleation and other modes are low in the boundary layer. Experiments with both binary and activation-type nucleation flatten the vertical profile by increasing concentrations in the lower troposphere and by reducing the binary nucleation peak in the upper troposphere. Part of the difference between the B and A simulations in 

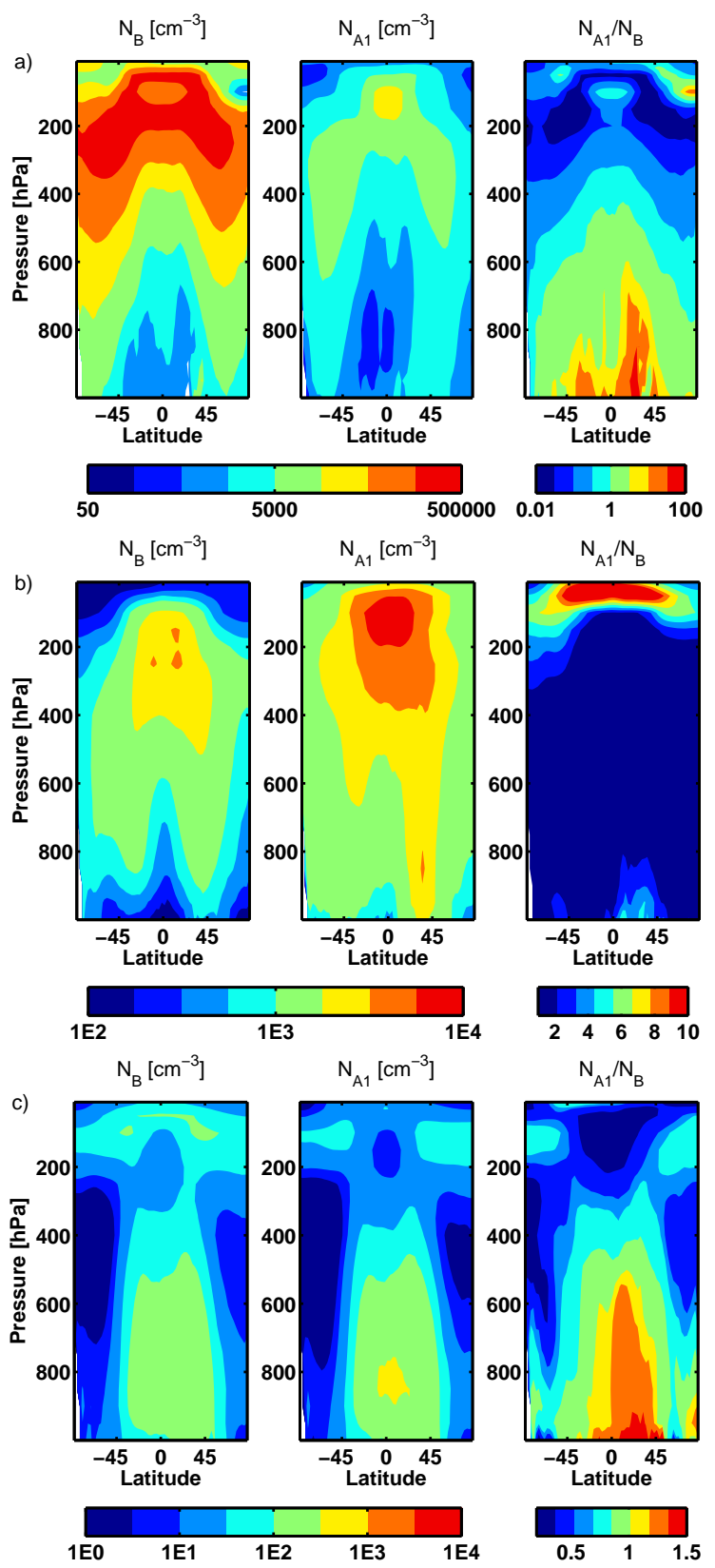
$\mathrm{N}_{\mathrm{A} 1} / \mathrm{N}_{\mathrm{B}}$

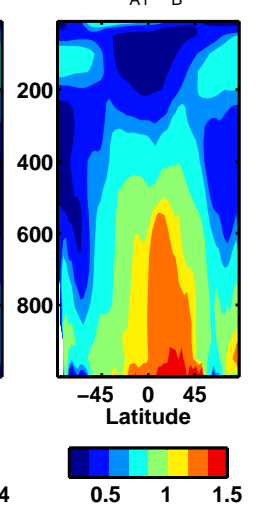

Fig. 2. Annual zonal average concentrations $\left(\mathrm{cm}^{-3}\right.$ STP $(1013.25 \mathrm{hPa}, 273.15 \mathrm{~K})$ ) of (a) nucleation mode aerosol number; (b) sum of Aitken mode number concentration; and (c) sum of accumulation mode number concentration. Left panels show the experiment B (standard ECHAM-HAM); centre ones experiment A1 (using activation nucleation in addition to the standard binary nucleation); and right panels show the ratio of the yearly averages for experiments B and A1. Notice the different color scales between figures.

Fig. 1 stems from the fact that experiments with activationtype nucleation use Eq. (2) to scale nucleation rate to $J_{3 \mathrm{~nm}}$.
Thus, the average radius of nucleation mode particles in the upper troposphere is smaller in experiment B than in experiments A0, A1 and A2. This can be seen indirectly in Fig. 1 when comparing concentration of nucleation mode particles to concentration of particles in larger modes. In the upper troposphere, nucleation mode concentrations produced only with binary nucleation are much larger than concentrations of larger particles, since only a small fraction of nucleation mode particles grow to larger sizes. The difference between the concentrations is smaller in activation-type experiments, since the average nucleation mode radius is already closer to Aitken mode radius. By taking this into account, solid lines in Fig. 1 are more comparable with each other, since they exclude nucleation mode concentration. It can be seen that even the smallest activation coefficient (experiment A0) increases the total number concentrations by a factor of 2.5 at the surface.

In Fig. 2, aerosol number concentrations in different size classes are compared between binary nucleation and activation-type nucleation. Figure 2 a shows that binary nucleation produces large number concentrations in regions where the temperature and pre-existing aerosol surface area are low. This leads to a band of particles between $100 \mathrm{hPa}$ and $300 \mathrm{hPa}$ with increased concentrations also in lower tropospheric polar areas. In general, concentrations in the lower troposphere are low with only a small increase near $30^{\circ} \mathrm{N}$. This lack of particles in the lower atmosphere at mid latitudes is mainly caused by low binary nucleation rates.

A feature of the original ECHAM5-HAM binary nucleation scheme is the absence of Aitken and accumulation mode particles in the upper troposphere at the equator, between 100-200 hPa, which is visible even in annual average concentrations shown in Stier et al. (2005). This behavior is partly due to a minor technical error in the application of Vehkamäki et al. (2001) parameterization in this region: the ECHAM5-HAM formulation sets the nucleation rate to zero outside the validity range of the parameterization. However, even when the values at the limit of the validity range are used when the arguments are outside of the validity range, the tropopause concentrations of nucleation mode particles are less in the tropics than in middle latitudes, even though the difference is much smaller than in Fig. $4 a$ of Stier et al. (2005).

Results from experiment A1 (middle panel in Fig. 2) show a similar, but weaker concentration band in the upper troposphere and increased concentrations below $700 \mathrm{hPa}$, as compared with experiment B. The ratio of concentrations (rightmost panel in Fig. 2a) shows that activation-type nucleation increases surface-layer concentrations of nucleation mode particles between $40^{\circ} \mathrm{S}-50^{\circ} \mathrm{N}$ by an order of magnitude, and concentrations at around $30^{\circ} \mathrm{N}$ are even 100 times higher than those with the binary nucleation scheme only, mostly due to large sulphur emissions. In the upper troposphere, activation-type nucleation decreases nucleation mode particle concentrations significantly. However, this effect stems 
mainly from the fact that the average radii of nucleation mode particles produced by binary nucleation (experiment B) are significantly (2-3 times) smaller than those observed in experiment A1. Again, number concentrations of particles in larger modes are more comparable with each other.

The results for Aitken and accumulation mode (Fig. 2b and c) are interesting for climate considerations, since nucleation mode particles themselves are too small to be activated into cloud droplets or to interact with atmospheric radiation. Activation-type nucleation increases Aitken mode number concentrations by a factor of 2-3 throughout the surface layer with a high increase near $30^{\circ} \mathrm{N}$. In contrast to the nucleation mode, Aitken mode particle number concentrations are increased throughout the atmosphere, with an order of magnitude increase at $100 \mathrm{hPa}$. This also demonstrates that nucleation mode particles are effectively growing into the Aitken mode. The growth continues until accumulation mode sizes, as can be seen from the increased concentrations of Fig. 2c. While the spatial patterns of nucleation mode and Aitken mode concentrations are significantly altered, the spatial distribution of accumulation mode particles is quite similar in experiments B and A1: concentrations in the boundary layer are somewhat increased and upper troposphere concentrations show a small decrease. This arises from primary emissions being the major source for accumulation mode particles. The effect on coarse mode particles was insignificant; changes are purely due to indirect changes in atmospheric dynamics, especially loss processes for largest aerosol particles (e.g. precipitation).

\subsection{Sensitivity to the value of activation coefficient}

Since the activation coefficient $A$ in Eq. (5) was originally derived from experimental data with limited geographical scale (mostly from boreal forest), it is necessary to investigate how sensitive the aerosol concentrations are to the chosen value of this coefficient. As all the physical and chemical factors affecting the coefficient are currently not known, we have used a constant value for all atmospheric conditions. This choice enables us to estimate the sensitivity of the aerosol concentrations and CDNC to this parameter and to make first estimates of the realistic range of this parameter for further studies.

Figure 3 shows the annual arithmetic-average formation rate of $3 \mathrm{~nm}$ particles with activation-type nucleation, and Fig. 4 shows the resulting annual-average nucleation mode particle number concentration in the surface layer for different values of the activation parameter. As expected, the sensitivity of the particle number concentration to the value of A is much lower than the sensitivity of the particle formation rate. The spatial distribution of the total number concentration over the continents does not change drastically between experiments A0, A1 and A2. The largest differences can be found in maritime regions, both in continental outflow and over remote ocean areas. Interestingly, results show very lit-
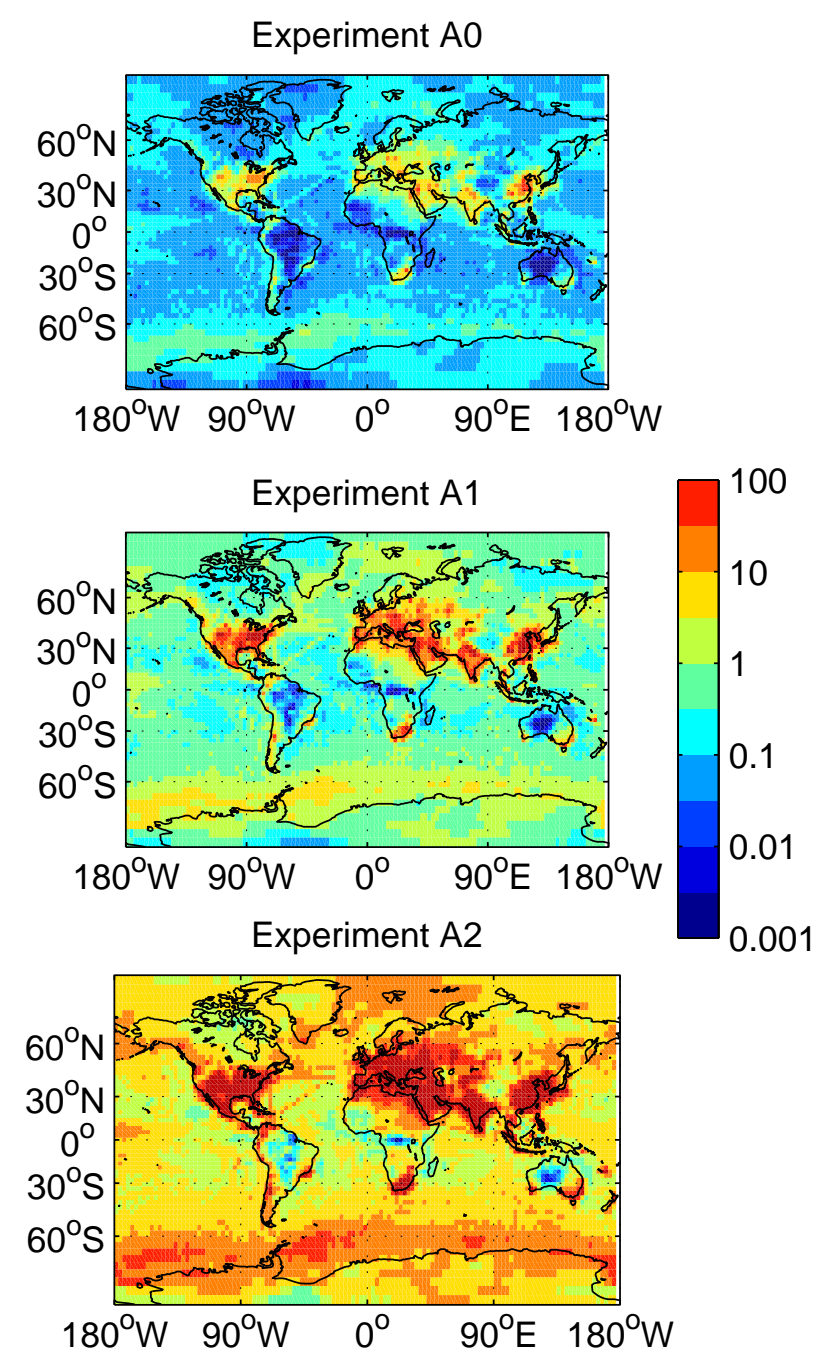

Fig. 3. Annual average formation rates $\left(\mathrm{cm}^{-3} \mathrm{~s}^{-1}\right)$ of $3 \mathrm{~nm}$ particles in the surface layer using different values for activation coefficient $\mathrm{A}$.

tle nucleation in tropical rainforest regions of South America, which is in agreement with observations (Rissler et al., 2006).

\subsection{Distribution of BSOA over the particle population}

The total amount of BSOA produced in our simulations varied in the range 3.2-19 Tg/year, depending on which aerosol yield (see Table 1) we assumed. Other model estimates of the present-day global BSOA production rate range between 13-24 Tg/year derived by Griffin et al. (1999), 61-79 Tg/year given by Kanakidou et al. (2000), 2.5-44 Tg/year given by Tsigaridis and Kanakidou (2003), 14.2 and 23.3 Tg/year obtained by Lack et al. (2004) using two different approaches, and $52-66 \mathrm{Tg} / \mathrm{year}$ derived by Hoyle et al. (2007). Finally, Goto et al. (2008) obtained a production rate of $6.7 \mathrm{Tg} / \mathrm{year}$ 

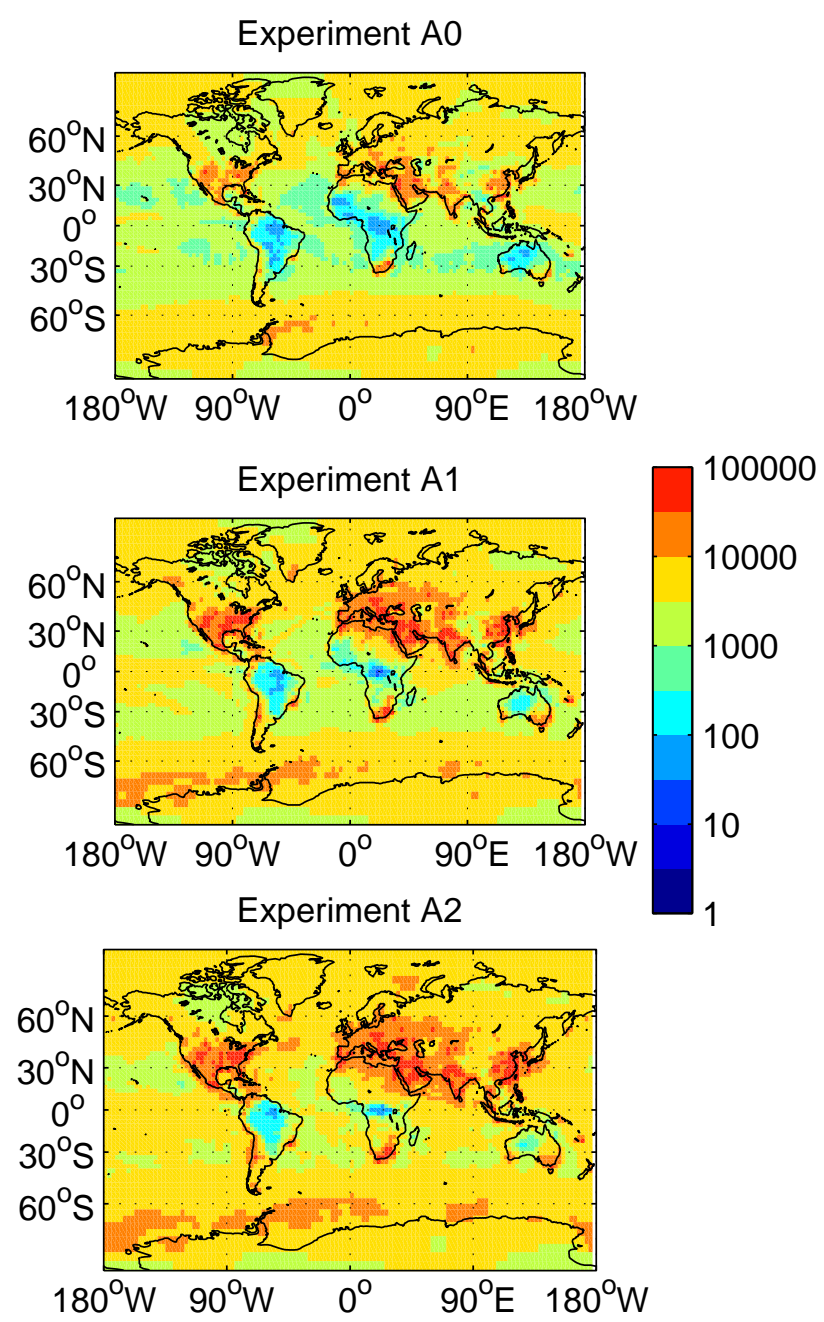

Fig. 4. Annual average nucleation mode number concentration $\left(\mathrm{cm}^{-3}\right)$ in the surface layer.

for BSOA resulting from monoterpenes alone. We conclude that the amount of BSOA produced in our simulation is within, even though at the lower edge of, the values obtained in more detailed global model investigations.

In the following, we investigate how the treatment of BSOA formation affects the simulated aerosol properties. Although the modified mechanism we use is rather simple, it is important to know how much the physical representation of the condensation will affect the partitioning of organic species in the aerosol distribution, and how much this affects particle growth and eventually CDNC.

The original ECHAM5-HAM uses constant size and solubility distribution for BSOA emissions. Figure 5 shows how the hybrid BSOA formation model partitions biogenic organic mass between the soluble Aitken and accumulation modes. The original ECHAM5-HAM assumes a 1:1 partitioning between these modes. On the average, this assumption is rather good in northern hemispheric remote areas, but for many important BSOA source regions organics are condensing mostly on larger particles. In equatorial areas in both Africa and South America the accumulation mode can even be a ten times more efficient sink for BSOA than the Aitken mode. Actually the hybrid BSOA formation scheme has two counteracting effects regarding CDNC. It allows the condensation of organics onto the nucleation mode and hence provides additional growth for freshly-formed aerosols, which increases Aitken mode particle concentrations and thereby CDNC. However, with the hybrid BSOA scheme, more organic mass is partitioned to the accumulation mode compared with the Aitken mode, which on the average decreases CDNC when compared to the original scheme. Figure 5 shows that over boreal forest areas, the Aitken mode is a significant sink for BSOA and hence the hybrid BSOA formation scheme would increase CDNC.

The hybrid BSOA formation scheme does not make any assumption about the solubility of the condensing organics; all seven modes are equally likely to act as condensational sinks for the organics. The original ECHAM5-HAM assumes that $65 \%$ of the biogenic organic vapors are soluble. Figure 6 shows how different the situation is with the hybrid model. It can be seen that the majority of the organic mass is condensing onto the soluble modes. Condensation onto the insoluble modes reaches a maximum of $\sim 30 \%$ in areas where significant concentrations of insoluble aerosols are available. Soluble modes are preferred by the hybrid BSOA formation scheme, since their surface area on the global scale is larger than in insoluble modes.

3.4 Effects of nucleation mechanisms and BSOA formation to aerosol number concentrations at the surface

Table 2 compares annual median predicted aerosol number concentrations to measured values at several locations. Concentrations are provided as $\mathrm{CN} 10$ (particle diameter $>10 \mathrm{~nm}$ ) and $\mathrm{CN} 100(>100 \mathrm{~nm})$. We consider CN10 as a representative of the particle number concentration outside the immediate range of nucleation and $\mathrm{CN} 100$ as a rough estimate of $\mathrm{CCN}$. These choices were made for easy comparison with measurements. Activation-type nucleation increases CN10 by a factor of 2 or more (experiment A1 compared to B). The hybrid BSOA formation scheme can decrease CN10 in locations of low emissions fields of biogenic organic vapors (Zeppelin, Mace Head, ACE-1), but generally it increases CN10 by a few tens of percent compared to the primary emission scheme (experiment AS2 compared to A1). The effect of BSOA scheme on CN100 is not as clear, but the use of hybrid BSOA formation scheme seems to decrease CN100. There is no clear correlation between BSOA yield and $\mathrm{CN} 10$ or CN100, although increasing BSOA yield seems to increase concentrations in certain locations.

For the CN10, inclusion of activation-type nucleation significantly improves model results for Hyytiälä, Melpitz, Mace Head, ACE-1 and ACE-2. For Hohenpeissenberg, the 


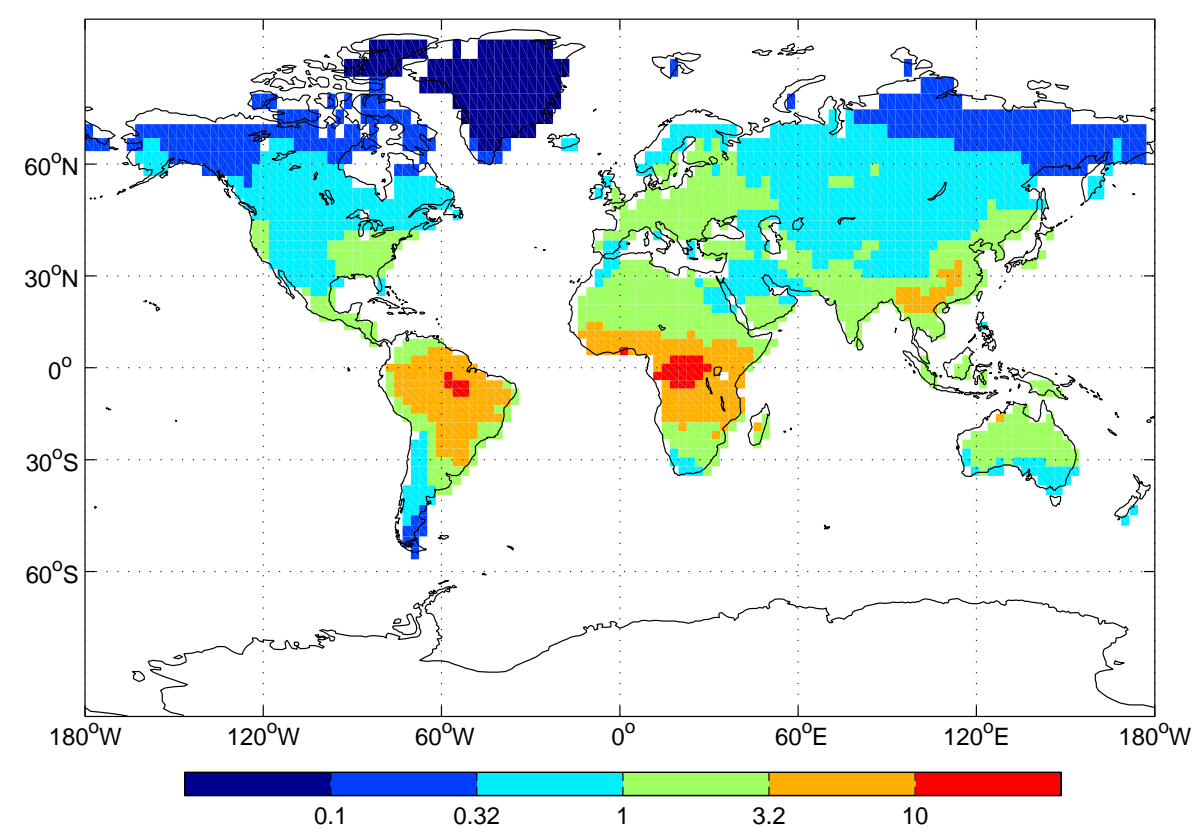

Fig. 5. Ratio (flux to soluble accumulation mode)/(flux to soluble Aitken mode) for biogenic organics using hybrid BSOA formation mechanism (experiment AS2). Standard ECHAM5-HAM assumes a 1:1 ratio.

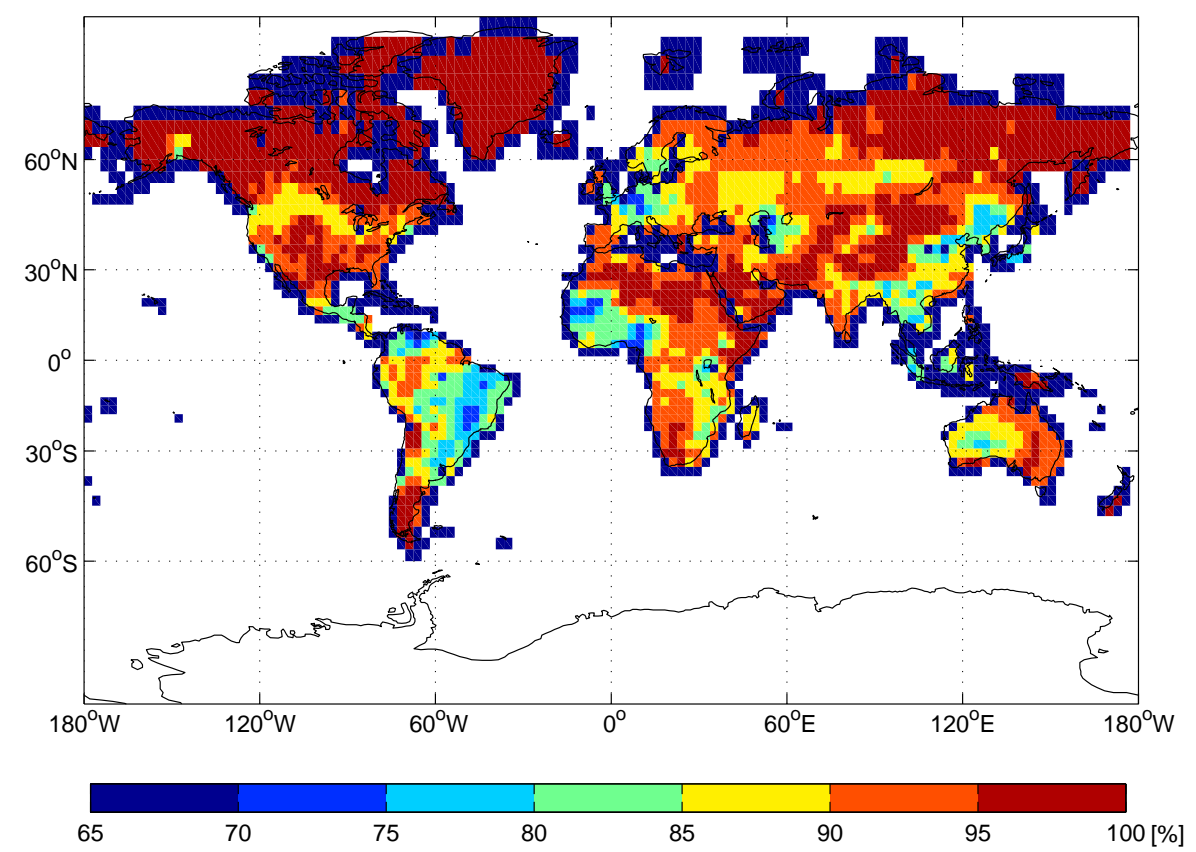

Fig. 6. Fraction of biogenic organics condensing to soluble modes in experiment AS2. In standard ECHAM5-HAM, a constant fraction of $65 \%$ is assumed, however, in experiment AS2, grid box average is always above $65 \%$.

result from experiment $\mathrm{A} 0$ is almost as close to observation as experiment B. Activation-type nucleation seems to overestimate CN10 for Zeppelin, Himalaya and Pallas. Concentrations of larger particles (CN100) are improved in Hyytiälä, Zeppelin, Mace Head and ACE-2. In Melpitz all experi- ment results are rather close to observed $\mathrm{CN} 100$, whereas in Hohenpeissenberg and ACE-1 all model results differ by more than a factor of 2 from observation. Also for Himalaya, the model is predicting too high $\mathrm{CN} 100$ in each experiment. However, the comparison with observations at Himalaya is a 
Table 2. Annual median number concentrations $\left(\mathrm{cm}^{-3}\right)$ of aerosol sizes $d_{p}>10 \mathrm{~nm}(\mathrm{CN} 10)$ and $d_{p}>100 \mathrm{~nm}(\mathrm{CN} 100)$ from observations and different experiments. On each row, closest model value to observation is emphasized. Observational data is taken from CREATE aerosol database (http://www.nilu.no/projects/ccc/create/database.htm), except for Himalaya and ACE-experiments.

\begin{tabular}{lllllllllll}
\hline CN10 & Obs. & B & A0 & A1 & A2 & AS1 & AS2 & S0 & S1 & S2 \\
\hline Hyytiälä & $1636^{\mathrm{a}}$ & 891 & $\mathbf{1 5 8 8}$ & 1919 & 1952 & 2286 & 2206 & 611 & 784 & 569 \\
Melpitz & $5032^{\mathrm{b}}$ & 2300 & $\mathbf{5 0 6 6}$ & 6354 & 7873 & 7622 & 8021 & 2344 & 2195 & 2253 \\
Hohenpeissenberg & $2502^{\mathrm{c}}$ & $\mathbf{2 2 8 9}$ & 3304 & 4182 & 4467 & 4724 & 5157 & 2119 & 2099 & 2257 \\
Zeppelin & $100^{\mathrm{d}}$ & 118 & 374 & 471 & 500 & 435 & 416 & $\mathbf{1 0 9}$ & 122 & 123 \\
Mace Head & $687^{\mathrm{e}}$ & 305 & $\mathbf{7 5 8}$ & 1171 & 1276 & 1080 & 1130 & 286 & 322 & 321 \\
Himalaya & $2093^{\mathrm{f}}$ & 2401 & 7000 & 9743 & 9856 & 9879 & 10354 & 1964 & $\mathbf{2 0 6 3}$ & 1988 \\
Pallas & $415^{\mathrm{g}}$ & $\mathbf{4 4 6}$ & 993 & 1201 & 1038 & 1517 & 1508 & 377 & 467 & 382 \\
ACE-1 & $1097^{\mathrm{h}}$ & 377 & 850 & $\mathbf{1 1 0 5}$ & 1222 & 1082 & 1043 & 835 & 401 & 368 \\
ACE-2 & $5337^{\mathrm{h}}$ & 1212 & $\mathbf{5 6 4 7}$ & 7562 & 9097 & 8000 & 9127 & 1011 & 1186 & 1323 \\
CN100 & & & & & & & & & & \\
Hyytiälä & $348^{\mathrm{a}}$ & 425 & 487 & 469 & 459 & 312 & $\mathbf{3 6 0}$ & 218 & 283 & 235 \\
Melpitz & $1099^{\mathrm{b}}$ & $\mathbf{1 0 9 1}$ & 1186 & 1238 & 1300 & 1220 & 1315 & 1143 & 1011 & 1054 \\
Hohenpeissenberg & $531^{\mathrm{c}}$ & 1339 & 1349 & 1352 & 1357 & 1223 & 1394 & 1176 & $\mathbf{1 1 3 1}$ & 1248 \\
Zeppelin & $41^{\mathrm{d}}$ & 26 & $\mathbf{4 1}$ & 41 & 38 & 29 & 29 & 23 & 26 & 22 \\
Mace Head & $140^{\mathrm{e}}$ & 60 & 104 & 150 & 131 & 120 & $\mathbf{1 4 9}$ & 59 & 67 & 73 \\
Himalaya & $948^{\mathrm{f}}$ & 1440 & 1574 & 1726 & 1658 & 1454 & 1491 & $\mathbf{1 1 8 6}$ & 1297 & 1220 \\
Pallas & $92^{\mathrm{g}}$ & 187 & 200 & 218 & 220 & 105 & 125 & 59 & $\mathbf{8 4}$ & 70 \\
ACE-1 & $22^{\mathrm{h}}$ & 69 & 94 & 104 & 94 & 107 & 98 & 195 & 69 & $\mathbf{6 8}$ \\
ACE-2 & $1672^{\mathrm{h}}$ & 495 & 919 & 1063 & $\mathbf{1 1 5 6}$ & 1126 & 1008 & 435 & 525 & 594 \\
\hline
\end{tabular}

${ }^{\mathrm{a}}$ Aalto et al. (2001), data from year 2000; ${ }^{\mathrm{b}}$ Engler et al. (2007), data from year 2003; ${ }^{\mathrm{c}}$ Birmili et al. (2003), data from year 2000; ${ }^{\mathrm{d}}$ Ström et al. (2003), data from year 2003; ${ }^{\mathrm{e}} \mathrm{O}$ 'Dowd et al. (1998), data from year 2003; ${ }^{\mathrm{f}}$ Komppula et al. (2008), data from year 2006; ${ }^{\mathrm{g}} \mathrm{Komppula}$ et al. (2003), data from year 2001; ${ }^{\text {h}}$ Heintzenberg et al. (2004), data from year 1995 (ACE-1) and 1997 (ACE-2)

bit unfair, since the same grid box contains emissions from urban Indian locations, while the air masses at the measurement site are rather clean. For the Pallas site, results from activation-type nucleation are rather close to observed values (experiment AS1).

\subsection{Effects of nucleation mechanisms and BSOA formation to cloud properties}

Both activation-type nucleation and hybrid BSOA formation scheme have significant effects on cloud droplet number concentrations. Since the cloud droplet activation model we use does not take aerosol composition into account, except in experiments B_SOLACT and A_SOLACT, changes in CDNC are only due to changes in the aerosol size distribution. Figure 7 shows how the combined effect of activation-type nu- cleation and hybrid BSOA formation scheme (experiment AS2) changes CDNC as compared with CDNC predicted by the original model. The figure shows a histogram of CDNC calculated from the annual mean distribution for the whole atmosphere, including only cloudy grid boxes. In original ECHAM5-HAM the majority (78\%) of cloudy grid boxes have a relatively low CDNC $\left(40-140 \mathrm{~cm}^{-3}\right)$, whereas only $51 \%$ of grid boxes in experiment AS2 reach these low values. The number of grid boxes with high CDNC values is significantly increased in experiment AS2 compared to experiment $\mathrm{B}$, with a factor of 1.8 in the range $140 \mathrm{~cm}^{-3}<\mathrm{CDNC}$ $<240 \mathrm{~cm}^{-3}$ and a factor of 3.3 for CDNC $>240 \mathrm{~cm}^{-3}$.

The qualitative effect on the CDNC distribution can be seen in Fig. 8, where CDNC in experiments B and AS2 is presented as a function of latitude and altitude. 
Table 3. Annual average CDNC $\left(\mathrm{cm}^{-3}\right)$ in selected areas (as seen in Fig. 12) in different experiments. The reference values are from Bennartz et al. (2007) and are results of two and a half year averages of satellite observations.

\begin{tabular}{llllll}
\hline Experiment & SAF & SAM & NAM & NEA & NAF \\
\hline B & 132 & 101 & 143 & 182 & 130 \\
A0 & 190 & 172 & 206 & 288 & 240 \\
A1 & 239 & 228 & 292 & 390 & 357 \\
A2 & 297 & 291 & 337 & 445 & 432 \\
AS1 & 241 & 229 & 295 & 392 & 363 \\
AS2 & 236 & 234 & 292 & 398 & 349 \\
S0 & 137 & 108 & 141 & 188 & 133 \\
S1 & 128 & 109 & 147 & 180 & 133 \\
S2 & 133 & 107 & 140 & 166 & 133 \\
B_SOLACT & 128 & 104 & 132 & 195 & 125 \\
A0_SOLACT & 184 & 167 & 221 & 284 & 252 \\
Reference value & $95 \pm 23$ & $77 \pm 36$ & $96 \pm 26$ & $129 \pm 23$ & $95 \pm 23$ \\
\hline
\end{tabular}

Similar spatial patterns can be seen in both experiments, which is due to similar annual-average cloud fields generated by ECHAM5-HAM, suggesting that activation-type nucleation did not have significant impact on general cloudiness in these short simulations. CDNC in the northern hemisphere reaches its maximum values at around $30^{\circ} \mathrm{N}$. The weaker maximum in the Southern Hemisphere originates from marine emissions and is located more towards the pole, between $30^{\circ} \mathrm{S}-60^{\circ} \mathrm{S}$. In the Northern Hemisphere, activation-type nucleation increases the average CDNC by more than $180 \mathrm{~cm}^{-3}$ below the $700 \mathrm{hPa}$ level around $30^{\circ} \mathrm{N}$. In the Southern Hemisphere a significant increase can be seen between $30^{\circ} \mathrm{S}-60^{\circ} \mathrm{S}$, where activation-type nucleation produces over $120 \mathrm{~cm}^{-3}$ additional CDNC below the $850 \mathrm{hPa}$ level. These large changes might have a significant impact on the radiative properties of clouds even on the global scale.

The sensitivity of CDNC against activation coefficient $A$ is presented in Fig. 9, which shows the annual zonal average $\mathrm{CDNC}$ in experiments $\mathrm{A} 0, \mathrm{~A} 1$ and $\mathrm{A} 2$. Increasing the activation coefficient from $2 \times 10^{-7} \mathrm{~s}^{-1}$ to $2 \times 10^{-6} \mathrm{~s}^{-1}$ leads to an average increase of $40 \%$ around $30^{\circ} \mathrm{N}$. The relative increase is generally around $20 \%$ in other areas. Experiment $\mathrm{A} 2$ shows less than a $10 \%$ average increase in CDNC compared to experiment A1. It must be noted that even experiment $\mathrm{A} 0$ produces significantly increased concentrations when compared with experiment B.

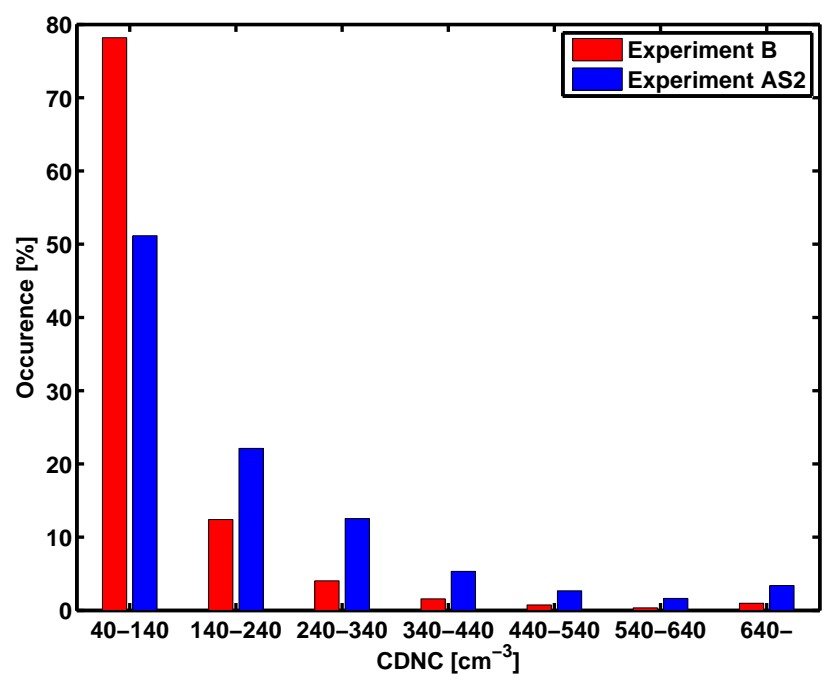

Fig. 7. Distribution of CDNC in annual mean global cloud-fields (sampled only from cloudy grid boxes) in experiments B and AS2. The minimum CDNC is set to $40 \mathrm{~cm}^{-3}$ in the cloud droplet activation model.

Vertical profiles in Fig. 10 provide a more general picture of CDNC in different experiments. Figure 10 shows that over land activation-type nucleation (experiment A1) increases CDNC by $50 \%$ above the $900 \mathrm{hPa}$ level, and that the effect is slightly stronger above oceans. Also the sensitivity to the activation coefficient is stronger in the maritime atmosphere. 

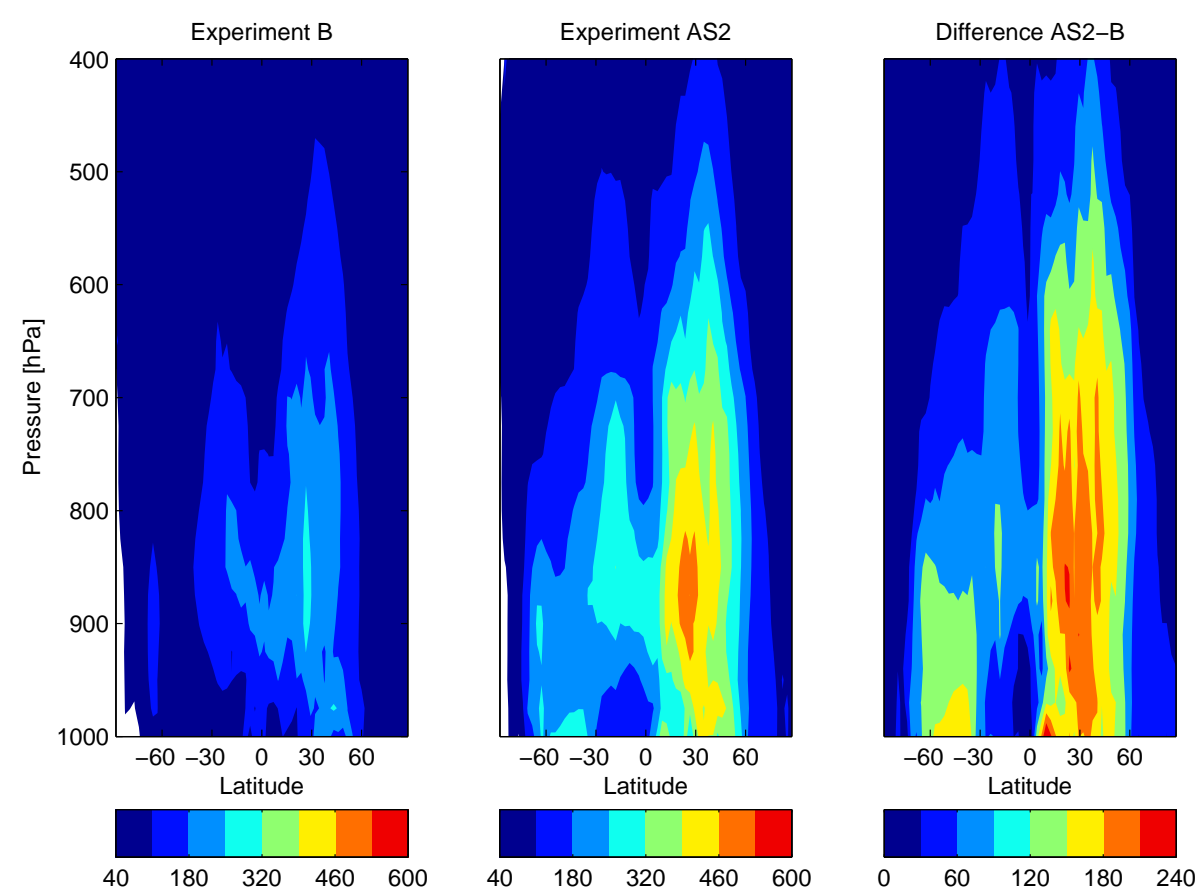

Fig. 8. Annual zonal average CDNC ( $\mathrm{cm}^{-3}$ sampled only from cloudy grid boxes) in experiments B and AS2 and their difference.
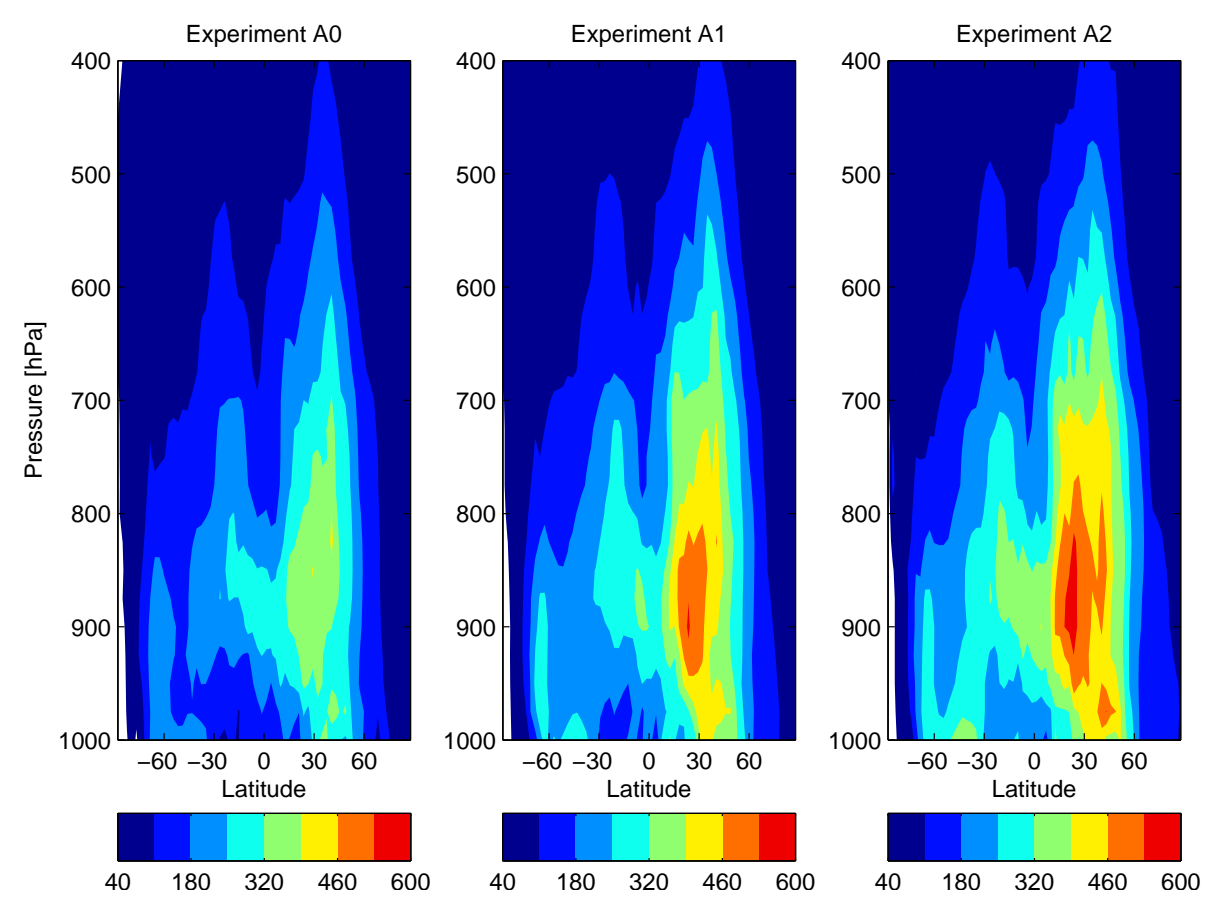

Fig. 9. Annual zonal average $\mathrm{CDNC}\left(\mathrm{cm}^{-3}\right.$ sampled only from cloudy grid boxes) with three different coefficients for activation-type nucleation: $2 \times 10^{-7} \mathrm{~s}^{-1}$ (A0), $2 \times 10^{-6} \mathrm{~s}^{-1}$ (A1) and $2 \times 10^{-5} \mathrm{~s}^{-1}$ (A2). 
This higher sensitivity to the nucleation method is due to the relatively higher proportion of CDNC in remote oceans from nucleation as the primary particle numbers and hence coagulation sinks in these areas are much lower. For a given nucleation mechanism, CDNC concentrations are lower when using the hybrid BSOA scheme as compared with the original treatment of BSOA partitioning. It can be seen that the global CDNC is rather insensitive to change in the BSOA yield between 0.025 and 0.15 . Since our model considers only continental BSOA sources, the BSOA scheme has practically no effect over oceans.

Figure 11 presents cloud-top CDNC over maritime regions in experiments B, B_SOLACT, A0 and A0_SOLACT together with data from MODIS instrument. Satellite-data is an average over years 2003-2006, and the details of the retrieval algorithm can be found from Bennartz et al. (2007). It can be seen that although binary nucleation produces generally too low aerosol concentrations, cloud-top CDNC is overestimated in experiment $\mathrm{B}$. Activation-type nucleation leads to even more overestimation compared to experiment B. There is some increase in all ocean basins, mainly near the coasts. Major differences are found, however, in regions of a continental outflow: west and east of North-America, west of Europe and South-Africa, and east of China due to higher nucleation rates over the continents. Parts of these areas are defined in Fig. 11 and examined in detail in Table 3. Binary nucleation overestimates cloud-top CDNC in these areas by $30-50 \%$, and experiments $\mathrm{A} 0, \mathrm{~A} 1$ and $\mathrm{A} 2$ increase cloud-top CDNC on average by a factor of 1.6, 2.2 and 2.7 in comparison with experiment $\mathrm{B}$, respectively.

3.6 Temporal variability of aerosol and cloud droplet number concentrations

Since our simulations do not use nudging of meteorological fields, we have to quantify the error caused by different meteorology in the experiments. In order to estimate the inter-annual variability of aerosol and cloud droplet concentrations, we extended experiment AS2 over a five-year simulation period. In case of the vertical profiles of aerosol concentrations (Fig. 1), the standard deviation for five distinct years is less than $1 \%$ of the corresponding annual average particle number concentrations. CDNC are more sensitive than aerosol concentrations to changes in model meteorology. The standard deviation of annual global average CDNC (Fig. 10) is less than $8 \mathrm{~cm}^{-3}$ above land. The difference in CDNC above land between experiments AS2 and B is 20 times larger than the inter-annual standard deviation. Above oceans the standard deviation is lower (maximum $4 \mathrm{~cm}^{-3}$ ) and the signal due to activation-type nucleation is over 30 times larger than the standard deviation. It should be noted that global averaging reduces the effect of inter-annual variability: the standard deviation of cloud-top CDNC in regions of Fig. 11 is about $15 \%$ of the difference between experiments AS2 and B.

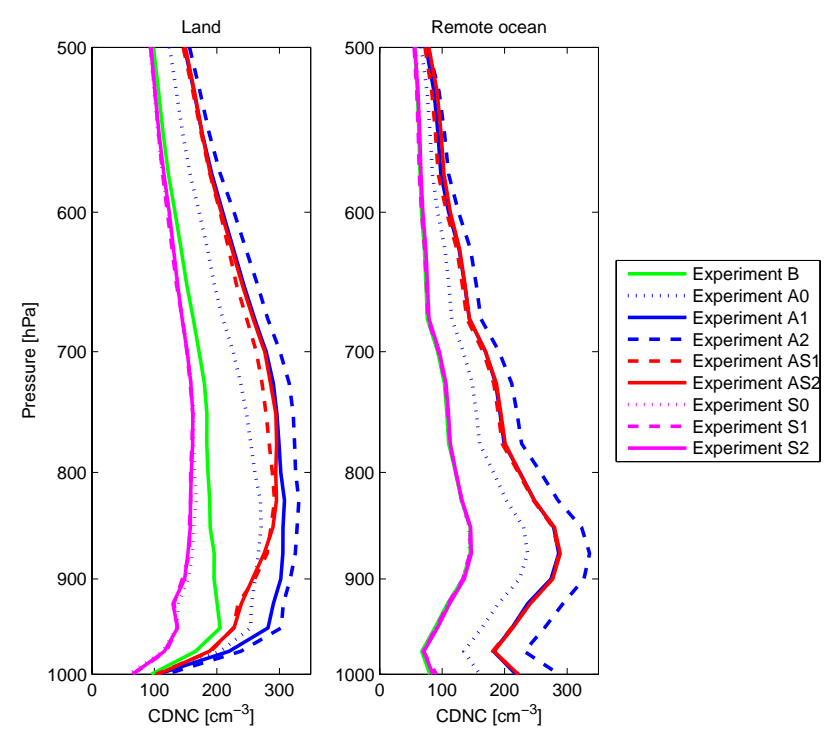

Fig. 10. Annual vertical average CDNC above land and remote oceans, sampled only from cloudy grid boxes. Experiment $\mathrm{B}$ is in green; experiments with activation-type nucleation (A0, A1, A2) in blue; experiments with hybrid BSOA formation scheme, but only binary nucleation in magenta $(\mathrm{S} 0, \mathrm{~S} 1, \mathrm{~S} 2)$; experiments with activation-type nucleation and hybrid BSOA formation scheme in red (AS1, AS2).

The intra-annual variability shows also a clear seasonal pattern. With activation-type nucleation, northernhemispheric aerosol concentrations are highest during the local summer (June and July). Concentrations in the Southern Hemisphere are generally lower, but as with the Northern Hemisphere, they have a peak during the local summer months (December to January).

\section{Discussion}

Our intention was to present the sensitivity of aerosol and cloud droplet number concentrations to nucleation and BSOA formation. By varying related parameters, such as activation coefficient or BSOA yield, we were able to determine the sensitivity of the aerosol and cloud systems.

Comparison of nucleation mechanisms showed a significant sensitivity to the used nucleation mechanism (binary or activation-type nucleation) and a slightly smaller sensitivity to the chosen activation coefficient. However, the use of a constant activation coefficient for the whole atmosphere requires some discussion. The activation coefficient is a semiempirical factor based on limited number of surface measurements (Kulmala et al., 2006). In contrast to the binary nucleation scheme used, which is based on solid thermodynamic basis, the activation-type nucleation process itself is not well known. For example, the exact relationships between the coefficient $A$ and other physical parameters are poorly known. Likewise, there are several indications that 

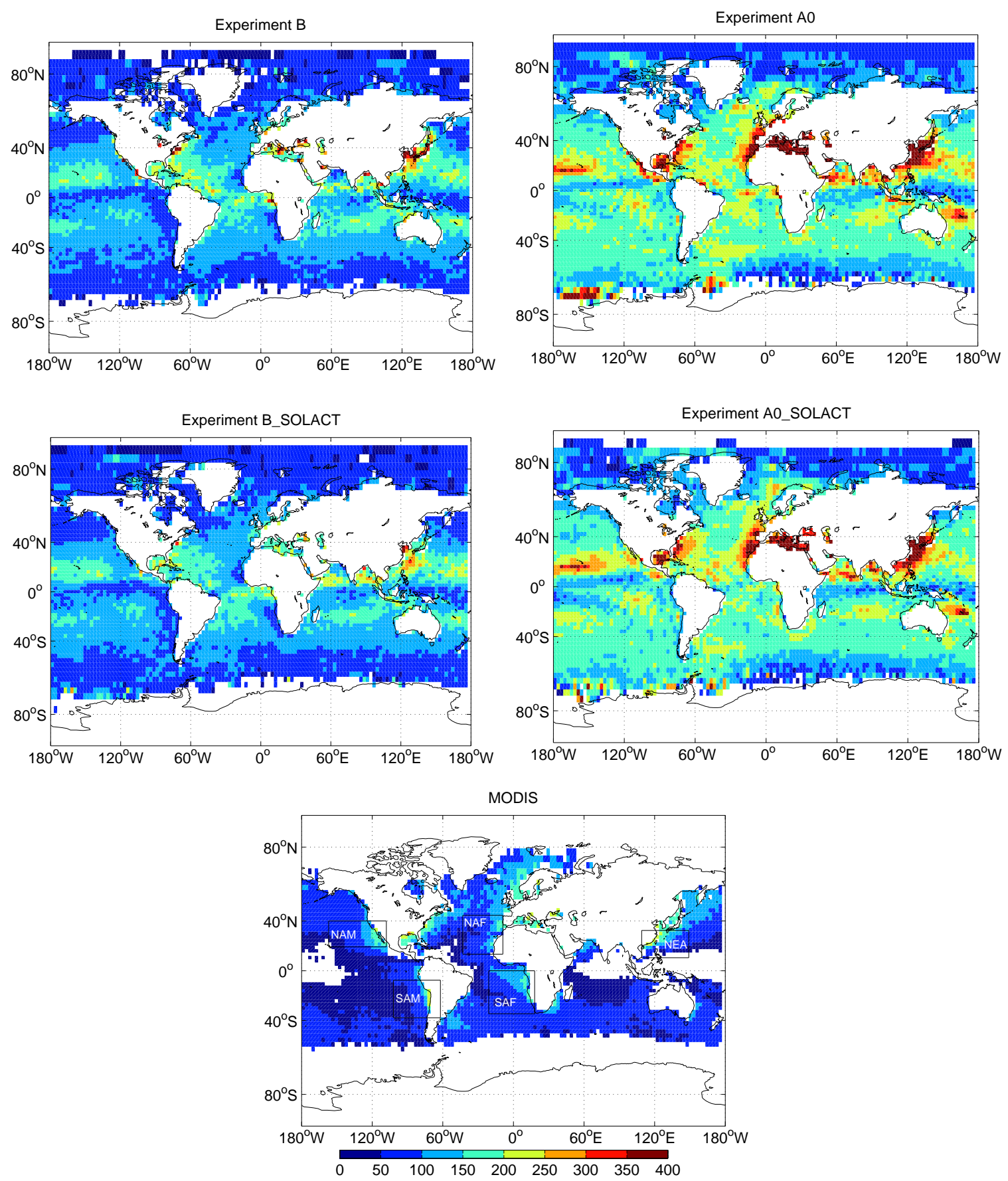

Fig. 11. Annual average cloud-top CDNC $\left(\mathrm{cm}^{-3}\right)$ sampled only over cloudy events in the cloudy part of the grid box in experiments $B$, B_SOLACT, A0 and A0_SOLACT, and MODIS derived cloud-top CDNC averaged over 2003-2006. The five areas shown below are chosen to match those of Bennartz et al. (2007).

the nucleation mechanism in the boundary layer is of either activation or kinetic type (e.g. Sihto et al., 2006; Riipinen et al., 2007; Kulmala et al., 2007; Kuang et al., 2008), it is still somewhat unclear whether activation nucleation is a realistic representation of new-particle formation in the global atmosphere. For these reasons, we can only study the sensitivity of other variables, such as aerosol and cloud droplet num- ber concentrations, against this coefficient. The coefficient $A$ is a surrogate for possibly many physical and chemical processes behind nucleation, and even though it seems to produce the observed particle formation events quite well near surface in many cases, the use of the same value in the upper atmosphere results in speculative results. The mechanism behind activation nucleation implicitly assumes that sulphuric 
acid forms stable particles with some other species (e.g. ions, other sulphur chemistry products or organics). However, a constant activation coefficient does imply that the concentrations of these "seeds" are constant in the atmosphere or at least that some competing process compensates changes in pre-existing clusters, which are most probably very rough approximations. On the other hand, recent observations support the idea that the concentration of atmospheric clusters near surface is relatively constant (Kulmala et al., 2007). If we could have more detailed information on the real chemical and physical nature of the activation nucleation, we could scale the coefficient better in upper atmosphere conditions.

In the binary nucleation case, nucleation and primary emissions together are unable to create realistic aerosol number concentrations in the lower troposphere using the ECHAM5-HAM model, as discussed by Stier et al. (2005). The activation nucleation gives, however, very promising results near the surface, creating quite realistic number concentrations of especially Aitken and accumulation modes, which are as yearly averages well comparable with average concentrations from continuous surface measurements. Comparisons in Table 2 show that, in general, experiments with activation-type nucleation typically give a better agreement in polluted regions but overestimate $\mathrm{CN} 10$ in remote areas. We attribute these overestimations partly to high average concentrations with high variability of apparent nucleation rates, which in turn is very closely connected with Eq. (2). Especially the exponent term is sensitive to the condensation sink (background aerosol concentration). In reality, it takes longer than one time step ( $30 \mathrm{~min})$ for newly nucleated aerosol particles to grow to detectable sizes. However, the parameterization of Kerminen and Kulmala (2002) uses only instantaneous aerosol distribution to calculate the removal prior to growth to detectable sizes and adds the surviving newly nucleated particles directly to the model grid box in the same time step. This approach is much more sensitive to local variations in the aerosol concentrations and sulphuric acid concentrations than a more detailed simulation on the smaller particles. However, the method of Kerminen and Kulmala (2002) is better suited for larger scale models: it does not increase the number of tracers, which improves the calculation efficiency, and it does include the main physical processes of growth and losses. Even with the current parameterization, the geometric means of the nucleation mode concentrations and nucleation rates are close to the observed values. This result, together with realistic values of Aitken mode number concentrations, gives some confidence in using this parameterization to obtain the effective nucleation source rate to the aerosol population near the surface. When comparing the results with experiment using the original binary nucleation, we must consider the poor performance of modal model representation of nucleation mode in case of strong simultaneous nucleation and growth: a fixed standard deviation of the nucleation mode distorts the particle number and size in comparison with more realistic size description. Also, all of the comparisons with measurements should be considered as qualitative, as all of the ECHAM5HAM simulations in this paper were done with model's own (non-nudged) meteorology. The use of a chemical transport model or nudging ECHAM5-HAM would make it easier to compare with field observations, but this study was designed as a sensitivity analysis including all feedback mechanisms of a GCM. The coarse spatial resolution causes problems when comparing with point observations: for example the Himalayan measurement station is located in a grid box with significant sulfur emissions from pollution sources, and the model seriously overestimates frequency of nucleation events.

Cloud droplet number concentration was shown to be sensitive to new-particle formation. Firstly, the implementation of activation-type nucleation increased aerosol number concentrations in the lower troposphere and hence provided more seeds for cloud droplets. Secondly, the hybrid BSOA formation scheme provided additional growth of freshly formed particles. The cloud droplet activation scheme used in this study had an activation diameter in the Aitken mode of the model, and therefore changes in the Aitken mode led directly to changes in CDNC. If a GCM framework does not include the possibility of cloud activation in the Aitken mode (as it seems to be the case in many modal models), the resulting CCN numbers might be severely underestimated. Part of the sensitivity estimate does, however, come from the chosen cloud-activation scheme.

Satellite observations provide information on the global scale for multi-year timescales. Unfortunately, instruments used in satellite observations are not able to give direct information about the aerosol size distribution or CDNC, but with several assumptions it is possible to use their estimates for comparison with model results. Figure 11 shows modeled cloud-top CDNC values together with values from MODIS. Although experiment with activation-type nucleation overestimates cloud-top CDNC compared to observation, activation-type nucleation can reproduce several patterns seen in satellite observations. There is generally no enhancement of CDNC near the coasts with binary nucleation except for east of China, however experiment A0 is shows observed enhancement around North America, east of Europe and Africa, and east of China. It is clear that CDNC produced by the model is too high, which can be due to several reasons, such as overestimation of cloud droplet activation, cloud thickness or minimum CDNC (Hoose et al., 2008). Even with a different cloud droplet activation scheme, experiment $\mathrm{B}$ would be unable to explain observed features of cloud-top CDNC. Also, the errata for Bennartz et al. (2007) (Bennartz and Harshvardhan, 2007) discusses the possibility of underestimating the CDNC values on the order of $10 \%$ in the presence of aerosols over clouds, which bring observations closer to model results.

In this study we assumed that the precursors and atmospheric properties related to new particle formation are 
constant in the whole grid box (grid distance of about $300 \mathrm{~km}$ at the equator) and during the model time step $(30 \mathrm{~min})$. These simplifications can create a bias in the model result, since in reality, the inhomogeneity in the unresolved scale in meteorological or aerosol fields can be significant. However, modern GCMs have very limited amount of information on subgrid-scale variations, and in the framework of this study we approached the problem simply by running ECHAM5HAM in different spatial resolutions. The results showed that the aerosol or cloud droplet number concentrations do not change significantly with varying resolutions. However, part of this result might be due to insufficient knowledge of the spatial inhomogeneity of sources and possibly due to the simplified linear nucleation method. It could be that nucleation mechanisms having a non-linear dependence on the sulphuric acid concentration might be more sensitive to resolution changes. Local nucleation rates might be heavily influenced by subgrid-scale changes in the coagulation sink. In many cases, e.g. biomass burning and direct anthropogenic emissions, sulphur dioxide and particle emissions are emitted simultaneously, which could affect nucleation rates in subgrid scales. There is a need for further studies on GCM subgrid-scale issues, in fields of both meteorology and aerosols.

We also assumed that the Eqs. (2-5) can be directly applied to the grid box averages, without taking the spatial scale into account. The assumption is somewhat justified as the equations have been tuned to work with large air masses. However, there is not enough knowledge on the nucleation process itself in order that we could argue that our implementation of simultaneous binary homogeneous nucleation and activation-type nucleation is correct. However, as discussed in Sect. 2.3, several implementations produce rather similar results for the quantities calculated in this study.

\section{Conclusions}

The simulations performed in this study show clearly that aerosol particle number concentrations and, perhaps more importantly, cloud droplet number concentrations in the ECHAM5-HAM model are sensitive to the aerosol nucleation mechanism used. Especially in the boundary layer and upper troposphere, aerosol number concentrations differ greatly depending on the choice of the nucleation mechanism. This sensitivity creates an additional problem for the global climate and earth system models to tackle the problem of realistic aerosol forcing. By using activationtype nucleation and hybrid BSOA formation method, we get a more realistic description of boundary-layer particle formation events: sulphuric acid activates some background species or ion forming clusters, which grows to $3 \mathrm{~nm}$ with sulphuric acid condensation and after $3 \mathrm{~nm}$ with the help of biogenic organic vapors. This complete set of processes could make it possible to better couple vegetation changes and changes in BVOC emissions due to climate change as a feedback back to the aerosols and climate.

The comparisons with observations show that activation nucleation is one very promising way to improve the ECHAM5-HAM model closer towards the average values observed over different locations, although the results show high temporal variability with occasionally unrealistically high number concentrations. Overestimation of nucleation rates and aerosol number concentrations can be due to several factors, such as too low primary emissions or the use of constant activation coefficient globally. CDNC comparisons to the satellite data show that activation-type nucleation reproduces several observed features, however the cloud droplet activation model used here overestimates CDNC even with only primary emissions and binary nucleation.

Acknowledgements. This work has been partly funded by European Commission EUCAARI project (Contract no. 36833) and the Academy of Finland (Project no. SA1111146). We thank the Finnish IT center for science (CSC) for technical support and computing time. We also thank the four anonymous reviewers and editor Øysten Hov for constructive comments, which helped to improve the manuscript.

Edited by: $\varnothing$. Hov

\section{References}

Aalto, P., Hämeri, K., Becker, E., Weber, R., Salm, R., Mäkelä, J. M., Hoell, C., O’Dowd, C. D., Karlsson, H., Hansson, H.C., Väkevä, M., Koponen, I. K., Buzorius, G., and Kulmala, M.: Physical characterization of aerosol particles during nucleation events, Tellus B, 53(4), 344-358, doi:10.1034/j.16000889.2001.530403.x, 2001.

Baker, M. B. and Peter, T.: Small-scale cloud processes and climate, Nature, 451, 299-300, 2008.

Bennartz, R.: Global assessment of marine boundary layer cloud droplet number concentration from satellite, J. Geophys. Res., 112, D02201, doi:10.1029/2006JD007547, 2007.

Bennartz, R. and Harshvardhan: Correction to "Global assessment of marine boundary layer cloud droplet number concentration from satellite”, J. Geophys. Res., 112, D16302, doi:10.1029/2007JD008841, 2007.

Birmili, W., Berresheim, H., Plass-Dülmer, C., Elste, T., Gilge, S., Wiedensohler, A., and Uhrner, U.: The Hohenpeissenberg aerosol formation experiment (HAFEX): a long-term study including size-resolved aerosol, $\mathrm{H}_{2} \mathrm{SO}_{4}, \mathrm{OH}$, and monoterpenes measurements, Atmos. Chem. Phys., 3, 361-376, 2003, http://www.atmos-chem-phys.net/3/361/2003/.

Bonn, B., von Kuhlmann, R., and Lawrence, M. G.: High contribution of biogenic hydroperoxides to secondary organic aerosol formation, Geophys. Res. Lett., 31, L10108, doi:10.1029/2003GL019172, 2004.

Camredon, M., Aumont, B., Lee-Taylor, J., and Madronich, S.: The SOA/VOC/NO $\mathrm{N}_{\mathrm{x}}$ system: an explicit model of secondary organic aerosol formation, Atmos. Chem. Phys., 7, 5599-5610, 2007, http://www.atmos-chem-phys.net/7/5599/2007/. 
Chen, J., Griffin, R. J., Grini, A., and Tulet, P.: Modeling secondary organic aerosol formation through cloud processing of organic compounds, Atmos. Chem. Phys., 7, 5343-5355, 2007, http://www.atmos-chem-phys.net/7/5343/2007/.

Chen, W.-T., Liao, H., and Seinfeld, J.: Future climate impacts of direct radiative forcing of anthropogenic aerosols, tropospheric ozone, J. Geophys. Res., 112, D14209, doi:10.1029/2006JD008051, 2007.

Chung, S. H. and Seinfeld, J. H.: Global distribution and climate forcing of carbonaceous aerosols, J. Geophys. Res., 107(D19), 4407, doi:10.1029/2001JD001397, 2002.

de Gouw, J. A., Brock, C. A., Atlas, E. L., Bates, T. S., Fehsenfeld, F. C., Goldan, P. D., Holloway, J. S., Kuster, W. C., Lerner, B. M., Matthew, B. M., Middlebrook, A. M., Onasch, T. B., Peltier, R. E., Quinn, P. K., Senff, C. J., Stohl, A., Sullivan, A. P., Trainer, M., Warneke, C., Weber, R. J., and Williams, E. J.: Sources of particulate matter in the northeastern United States in summer: 1. Direct emissions and secondary formation of organic matter in urban plumes, J. Geophys. Res., 113, D08301, doi:10.1029/2007JD009243, 2008.

Engler, C., Rose, D., Wehner, B., Wiedensohler, A., Brüggemann, E., Gnauk, T., Spindler, G., Tuch, T., and Birmili, W.: Size distributions of non-volatile particle residuals $(\mathrm{Dp}<800 \mathrm{~nm})$ at a rural site in Germany and relation to air mass origin, Atmos. Chem. Phys., 7, 5785-5802, 2007,

http://www.atmos-chem-phys.net/7/5785/2007/.

Ervens, B. and Kreidenweis, S. M.: SOA formation by biogenic and carbonyl compounds: Data evaluation and application, Environ. Sci. Technol., 41, 3904-3910, 2007.

Forster, P., Ramaswamy, V., Artaxo, P., Berntsen, T., Betts, R., Fahey, D. W., Haywood, J., Lean, J., Lowe, D. C., Myhre, G., Nganga, J., Prinn, R., Raga, G., Schulz, M., and Van Dorland, R.: Changes in Atmospheric Constituents and in Radiative Forcing, in: Climate Change 2007: The Physical Science Basis. Contribution of Working Group I to the Fourth Assessment Report of the Intergovernmental Panel on Climate Change, edited by: Solomon, S., Qin, D., Manning, M., Chen, Z., Marquis, M., Averyt, K. B., Tignor, M., and Miller, H. L., Cambridge University Press, Cambridge, United Kingdom and New York, NY, USA, 2007.

Guenther, A., Hewitt, C. N., Erickson, D., Fall, R., Geron, C., Graedel, T., Harley, P., Klinger, L., Lerdau, M., Mckay, W. A., Pierce, T., Scholes, B., Steinbrecher, R., Tallamraju, R., Taylor, J., and Zimmerman, P.: A global model of natural volatile organic compound emissions, J. Geophys. Res., 100(D5), 88738892, 1995.

Fuzzi, S., Andreae, M. O., Huebert, B. J., Kulmala, M., Bond, T. C., Boy, M., Doherty, S. J., Guenther, A., Kanakidou, M., Kawamura, K., Kerminen, V.-M., Lohmann, U., Russell, L. M., and Pöschl, U.: Critical assessment of the current state of scientific knowledge, terminology, and research needs concerning the role of organic aerosols in the atmosphere, climate, and global change, Atmos. Chem. Phys., 6, 2017-2038, 2006, http://www.atmos-chem-phys.net/6/2017/2006/.

Gaydos, T. M., Stanier, C. O., and Pandis, S. N.: Modeling of in situ ultrafine atmospheric particle formation in the eastern United States, J. Geophys. Res., 110, D07S12, doi:10.1029/2004JD004683, 2005.
Ghan, S. J. and Schwartz, S. E.: Aerosol properties and processes: A path from field and laboratory measurements to global climate models, Bull. Am. Meteor. Soc., 88, 1059-1083, 2007.

Goto, D., Takemura, T., and Nakajima, T.: Importance of global aerosol modeling including secondary organic aerosol formed from monoterpene, J. Geophys. Res., 113, D07205, doi:10.1029/2007JD009019, 2008.

Griffin, R. J., Cocker, D. R. III, Seinfeld, J. H., and Dabdud, D.: Estimate of global atmospheric organic aerosol from oxidation of biogenic hydrocarbons, Geophys. Res. Lett., 26, 2721-2724, 1999.

Griffin, R. J., Dabdub, D., and Seinfeld, J. H.: Development and initial evaluation of a dynamic species-resolved model for gas phase chemistry and size-resolved gas/particle partitioning associated with secondary organic aerosol formation, J. Geophys. Res., 110, D05304, doi:10.1029/2004JD005219, 2005.

Guillaume, B., Liousse, C., Rosset, R., Carchier, H., Van Velthoven, P., Bessagnet, B., and Poisson, N.: ORISAM-TM4: a new global sectional multi-component aerosol model including SOA formation - Focus on carbonaceous BC and OC aerosols, Tellus, 59B, 283-302, 2007.

Heald, C. L., Jacob, D. J., Park, R. J., Russell, L. M., Huebert, B. J., Seinfeld, J. H., Liao, J., and Weber, R. J.: A large organic aerosol source in the free troposphere missing from current models, Geophys. Res. Lett., 32, L18809, doi:10.1029/2005GL023831, 2005.

Heintzenberg, J., Birmili, W., Wiedensohler, A., Nowak, A., and Tuch, T.: Structure, variability and persistence of the submicrometre marine aerosol, Tellus, 56B, 357-367, 2004.

Henze, D. K. and Seinfeld, J. H.: Global secondary organic aerosol from isoprene oxidation. Geophys. Res. Lett., 33, L09812, doi:10.1029/2006GL025976, 2006.

Hoose, C., Lohmann, U., Bennartz, R., Croft, B., and Lesins, G.: Global simulations of aerosol processing in clouds, Atmos. Chem. Phys., 8, 6939-6963, 2008, http://www.atmos-chem-phys.net/8/6939/2008/.

Hoyle, C. R., Berntsen, T., Myhre, G., and Isaksen, I. S. A.: Secondary organic aerosol in the global aerosol chemical transport model Oslo CTM2, Atmos. Chem. Phys., 7, 5675-5694, 2007, http://www.atmos-chem-phys.net/7/5675/2007/.

Jones, A., Haywood, J. M., and Boucher, O.: Aerosol forcing, climate response and climate sensitivity in the Hadley Centre climate model, J. Geophys. Res., 112, D20211, doi:10.1029/2007JD008688, 2007.

Kanakidou, M., Tsigaridis, K., Dentener, F., and Crutzen, P. J.: Human-activity-enhanced formation of organic aerosols by biogenic hydrocarbon oxidation, J. Geophys. Res., 105, 9243-9254, 2000.

Kanakidou, M., Seinfeld, J. H., Pandis, S. N., Barnes, I., Dentener, F. J., Facchini, M. C., Van Dingenen, R., Ervens, B., Nenes, A., Nielsen, C. J., Swietlicki, E., Putaud, J. P., Balkanski, Y., Fuzzi, S., Horth, J., Moortgat, G. K., Winterhalter, R., Myhre, C. E. L., Tsigaridis, K., Vignati, E., Stephanou, E. G., and Wilson, J.: Organic aerosol and global climate modelling: a review, Atmos. Chem. Phys., 5, 1053-1123, 2005, http://www.atmos-chem-phys.net/5/1053/2005/.

Kazil, J., Lovejoy, E. R., Barth, M. C., and O'Brien, K.: Aerosol nucleation over oceans and the role of galactic cosmic rays, Atmos. Chem. Phys., 6, 4905-4924, 2006, http://www.atmos-chem-phys.net/6/4905/2006/. 
Kazil, J. and Lovejoy, E. R.: A semi-analytical method for calculating rates of new sulfate aerosol formation from the gas phase, Atmos. Chem. Phys., 7, 3447-3459, 2007, http://www.atmos-chem-phys.net/7/3447/2007/.

Kerminen, V.-M. and Kulmala, M.: Analytical formulae connecting the "real" and the "apparent" nucleation rate and the nuclei number concentration for atmospheric nucleation events, J. Aerosol Sci., 33, 609-622, 2002.

Kerminen, V.-M., Anttila, T., Lehtinen, K. E. J., and Kulmala, M.: Parameterization for atmospheric new-particle formation: application to a system involving sulphuric acid and condensable water-soluble organic vapors, Aerosol Sci. Technol., 38, 10011008, 2004.

Kerminen, V.-M., Lihavainen, H., Komppula, M., Viisanen, Y., and Kulmala, M.: Direct observational evidence linking atmospheric aerosol formation and cloud droplet activation, Geophys. Res. Lett. 32, L14803, doi:10.1029/2005GL023130, 2005.

Komppula, M., Lihavainen, H., Hatakka, J., Paatero, J., Aalto, P., Kulmala, M., and Viisanen, Y.: Observations of new particle formation and size distributions at two different heights and surroundings in subarctic area in northern Finland, J. Geophys. Res., 108(D9), 4295, doi:10.1029/2002JD002939, 2003.

Komppula M., Lihavainen, H., Hyvärinen, A.-P., Kerminen, V.-M., Panwar, T. S., Sharma, V. P., and Viisanen, Y.: Physical properties of aerosol particles at a Himalayan background site in India, submitted, J. Geophys. Res., 2008.

Koponen, I. K., Virkkula, A., Hillamo, R., Kerminen, V.M., and Kulmala, M.: Number size distributions and concentrations of the continental summer aerosols in Queen Maud Land, Antarctica, J. Geophys. Res., 108(D18), 4587, doi:10.1029/2003JD003614, 2003.

Kuang, C., McMurry, P. H., McCormick, A. V., and Eisele, F. L.: Dependence of nucleation rates on sulfuric acid vapor concentration in diverse atmospheric locations, J. Geophys. Res., 113, D10209, doi:10.1029/2007JD009253, 2008.

Kulmala, M., Pirjola, L., and Mäkelä, J. M.: Stable sulphate clusters as a source of new atmospheric particles, Nature 404, 66-69, 2000.

Kulmala, M., Vehkamäki, H., Petäjä, T., Dal Maso, M., Lauri, A., Kerminen, V.-M., Birmili, W., and McMurry, P. H.: Formation and growth rates of ultrafine atmospheric particles: A review of observations, J. Aerosol Sci., 35, 143-176, 2004a.

Kulmala, M., Kerminen, V.-M., Anttila, T., Laaksonen, A., and O'Dowd, C. D.: Organic aerosol formation via sulphate cluster activation, J. Geophys. Res. 109(D4), 4205, doi:10.1029/2003JD003961, 2004b.

Kulmala, M., Lehtinen, K. E. J., and Laaksonen, A.: Cluster activation theory as an explanation of the linear dependence between formation rate of $3 \mathrm{~nm}$ particles and sulphuric acid concentration, Atmos. Chem. Phys., 6, 787-793, 2006, http://www.atmos-chem-phys.net/6/787/2006/.

Kulmala, M., Riipinen, I., Sipilä, M., Manninen, H. E., Petäjä, T., Junninen, H., Dal Maso, M., Mordas, G., Mirme, A., Vana, M., Hirsikko, A., Laakso, L., Harrison, R. M., Hanson, I., Leung, C., Lehtinen, K. E. J., and Kerminen, V.-M.: Toward direct measurement of atmospheric nucleation. Science 318, 8992, doi:10.1126/science.1144124, 2007b.

Laakso, L., Hussein, T., Aarnio, P., Komppula, M., Hiltunen, V., Viisanen, Y., and Kulmala, M..: Diurnal and annual characteris- tics of particle mass and number concentrations in urban, rural and Arctic environments in Finland. Atmos. Environ., 37, 26292641, doi:10.1016/S1352-2310(03)00206-1, 2003.

Laaksonen, A. Hamed, A., Joutsensaari, J., Hiltunen, L., Cavalli, F., Junkermann, W., Asmi, A., Fuzzi, S., and Facchini, M. C.: Cloud condensation nucleus production from nucleation events at a highly polluted region, Geophys. Res. Lett., 32, L06812, doi:10.1029/2004GL022092, 2005.

Lack, D. A., Tie, X. X., Bofinger, N. D., Wiegand, A. N., and Madronich, S.: Seasonal variability of secondary organic aerosol: A global modeling study, J. Geophys. Res., 109, D03203, doi:10.1029/2003JD003418, 2004.

Lehtinen, K. E. J., Dal Maso, M., Kulmala, M., and Kerminen, V.M.: Estimating nucleation rates from apparent particle formation rates and vice versa: Revised formulation of the KerminenKulmala equation, J. Aerosol Sci., 38, 988-994, 2007.

Lihavainen, H., Kerminen, V.-M., Komppula, M., Hatakka, J., Aaltonen, V., Kulmala, M., and Viisanen Y.: Production of "potential" cloud condensation nuclei associated with atmospheric newparticle formation in northern Finland, J. Geophys. Res., 108(D24), 4782, doi:10.1029/2003JD003887, 2003.

Lin, H. and Leaitch, W. R.: Development of an in-cloud aerosol activation parameterization or climate modelling, in: Proceedings of the WMO Workshop on Measurement of Cloud Properties for Forecasts of Weather, Air Quality and Climate, World Meteorol. Organ., Geneva, 328-335, 1997.

Liu, P. and Zhang, Y.: A computationally-efficient secondary organic aerosol module for three-dimensional air quality models, Atmos. Chem. Phys., 8, 3985-3998, 2008, http://www.atmos-chem-phys.net/8/3985/2008/.

Lohmann, U. and Feichter, J.: Global indirect aerosol effects: a review, Atmos. Chem. Phys., 5, 715-737, 2005, http://www.atmos-chem-phys.net/5/715/2005/.

Lohmann, U., Stier, P., Hoose, C., Ferrachat, S., Kloster, S., Roeckner, E., and Zhang, J.: Cloud microphysics and aerosol indirect effects in the global climate model ECHAM5-HAM, Atmos. Chem. Phys., 7, 3425-3446, 2007, http://www.atmos-chem-phys.net/7/3425/2007/.

Lucas, D. D. and Akimoto, H.: Evaluating aerosol nucleation parameterizations in a global atmospheric model, Geophys. Res. Lett., 33, L10808, doi:10.1029/2006GL025672, 2006.

McMurry, P. H., Fink, M., Sakurai, H., Stolzenburg, M. R., Mauldin, R. L., Smith, J, Eisele, F., Moore, K., Sjostedt, S., Tanner, D., Huey, L. G., Nowak, J. B., Edgerton, E., and Voisin, D.: A criterion for new particle formation in the sulfur-rich Atlanta atmosphere, J. Geophys. Res., 110, D22S02, doi:10.1029/2005JD005901, 2005.

Merikanto, J., Napari, I., Vehkamäki, H., Anttila, T., and Kulmala, M.: New parameterization of sulphuric acid-ammoniawater ternary nucleation rates at tropospheric conditions, J. Geophys. Res., 11, D15207, doi:10.1029/2006JD007977, 2007.

Miles, N. L., Verlinde, J., and Clothiaux, E. E.: Cloud droplet size distributions in low-level stratiform clouds, J. Atmos. Sci. 57, 295-311, 2000.

Modgil, M. S., Kumar, S., Tripathi, S. N., and Lovejoy, E. R.: A parameterization of ion-induced nucleation of sulphuric acid and water for atmospheric conditions, J. Geophys. Res., 110, D19205, doi:10.1029/2004JD005475, 2005. 
Napari, I., Noppel, M., Vehkamäki, H., and Kulmala, M.: Parameterization of ternary nucleation rates for $\mathrm{H}_{2} \mathrm{SO}_{4}$ $\mathrm{NH}_{3}-\mathrm{H}_{2} \mathrm{O}$ vapors, J. Geophys. Res., 107(D19), 4381, doi:10.1029/2002JD002132, 2002.

Ng, N. L., Chhabra, P. S., Chan, A. W. H., Surratt, J. D., Kroll, J. H., Kwan, A. J., McCabe, D. C., Wennberg, P. O., Sorooshian, A., Murphy, S. M., Dalleska, N. F., Flagan, R. C., and Seinfeld, J. H.: Effect of $\mathrm{NO}_{\mathrm{x}}$ level on secondary organic aerosol (SOA) formation from the photooxidation of terpenes, Atmos. Chem. Phys., 7, 5159-5174, 2007, http://www.atmos-chem-phys.net/7/5159/2007/.

O'Dowd, C. D., Geever, M., Hill, M. K., Smith, M. H., and Jennings S. G.: New Particle Formation: Nucleation Rates and Spatial Scales in the Clean Marine Coastal Environment, Geophys. Res. Lett., 25(10), 1661-1664, 1998.

Penner, J. E., Quaas, J., Storelvmo, T., Takemura, T., Boucher, O., Guo, H., Kirkevåg, A., Kristjánsson, J. E., and Seland, Ø.: Model intercomparison of indirect aerosol effects, Atmos. Chem. Phys., 6, 3391-3405, 2006,

http://www.atmos-chem-phys.net/6/3391/2006/.

Pierce, J. R., Chen, K., and Adams, P. J.: Contribution of primary carbonaceous aerosol to cloud condensation nuclei: processes and uncertainties evaluated with a global aerosol microphysics model, Atmos. Chem. Phys., 7, 5447-5466, 2007,

http://www.atmos-chem-phys.net/7/5447/2007/.

Pun, B. K. and Seigneur, C.: Investigative modeling of new pathways for secondary organic aerosol formation, Atmos. Chem. Phys., 7, 2199-2216, 2007,

http://www.atmos-chem-phys.net/7/2199/2007/.

Riipinen, I., Sihto, S.-L., Kulmala, M., Arnold, F., Dal Maso, M., Birmili, W., Saarnio, K., Teinil, K., Kerminen, V.-M., Laaksonen, A., and Lehtinen, K. E. J.: Connections between atmospheric sulphuric acid and new particle formation during QUEST IIIIV campaigns in Heidelberg and Hyytiälä, Atmos. Chem. Phys., 7, 1899-1914, 2007,

http://www.atmos-chem-phys.net/7/1899/2007/.

Rissler, J., Vestin, A., Swietlicki, E., Fisch, G., Zhou, J., Artaxo, P., and Andreae, M. O.: Size distribution and hygroscopic properties of aerosol particles from dry-season biomass burning in Amazonia, Atmos. Chem. Phys., 6, 471-491, 2006, http://www.atmos-chem-phys.net/6/471/2006/.

Robinson, A. L., Donahue, N. M., Shrivastava, M. K., Weitkamp, E. A., Sage, A. M., Grieshop, A. P., Lane, T. E., Pierce, J. R., and Pandis, S. N.: Rethinking organic aerosols: Semivolatile emissions and photochemical aging, Science, 315, 1259-1262, 2007.

Roelofs, G. J.: A GCM study of organic matter in marine aerosol and its potential contribution to cloud drop activation, Atmos. Chem. Phys., 8, 709-719, 2008,

http://www.atmos-chem-phys.net/8/709/2008/.

Shindell, D. T., Faluvegi, G., Bauer, S. E., Koch, D., Unger, N., Menon, S., Miller R. L., Schmidt, G. A, and Streets, D. G.: Climate response to projected changes in short-lived species under an A1B scenario from 2000-2050 in the GISS climate model, J. Geophys. Res., 112, D20103, doi:10.1029/2007JD008753, 2007.

Sihto, S.-L., Kulmala, M., Kerminen, V.-M., Dal Maso, M., Petäjä, T., Riipinen, I., Korhonen, H., Arnold, F., Janson, R., Boy, M., Laaksonen, A., and Lehtinen, K. E. J.: Atmospheric sulphuric acid and aerosol formation: implications from atmospheric measurements for nucleation and early growth mechanisms, Atmos.
Chem. Phys., 6, 4079-4091, 2006,

http://www.atmos-chem-phys.net/6/4079/2006/.

Spracklen, D. V., Carslaw, K. S., Kulmala, M., Kerminen, V.-M., Mann, G. W., and Sihto, S.-L.: The contribution of boundary layer nucleation events to total particle concentrations on regional and global scales, Atmos. Chem. Phys., 6, 5631-5648, 2006, http://www.atmos-chem-phys.net/6/5631/2006/.

Spracklen, D. V., Carslaw, K. S., Kulmala, M., Kerminen, V.-M., Sihto, S.-L., Riipinen, I., Merikanto, J., Mann, G. W., Chipperfield, M. P., Wiedensohler, A., Birmili, W., and Lihavainen H.: Contribution of particle formation to global cloud condensation nuclei concentrations, Geophys. Res. Lett., 35, L06808, doi:10.1029/2007GL033038, 2008.

Spracklen, D. V., Arnold, S. R., Sciare, J., Carslaw, K. S., and Pio, C. A.: Globally significant oceanic source of organic carbon aerosol, Geophys. Res. Lett., 35, L12811, doi:10.1029/2008GL033359, 2008b.

Stier, P., Feichter, J., Kinne, S., Kloster, S., Vignati, E., Wilson, J., Ganzeveld, L., Tegen, I., Werner, M., Balkanski, Y., Schulz, M., Boucher, O., Minikin, A., and Petzold, A.: The aerosolclimate model ECHAM5-HAM, Atmos. Chem. Phys., 5, 11251156, 2005, http://www.atmos-chem-phys.net/5/1125/2005/.

Ström, J., Umegård, J., Tørseth, K., Tunved, P., Hansson, H.-C., Holmén, K., Wismann, V., Herber, A., and König-Langlo, G.: One year of particle size distribution and aerosol chemical composition measurements at the Zeppelin Station, Svalbard, March 2000-March 2001, Phys. Chem. Earth, 28, 1181-1190, 2003.

Suni, T., Kulmala, M., Hirsikko, A., Bergman, T., Laakso, L., Aalto, P. P., Leuning, R., Cleugh, H., Zegelin, S., Hughes, D., van Gorsel, E., Kitchen, M., Vana, M., Hõrrak, U., Mirme, S., Mirme, A., Sevanto, S., Twining, J., and Tadros, C.: Formation and characteristics of ions and charged aerosol particles in a native Australian Eucalypt forest, Atmos. Chem. Phys., 8, 129-139, 2008, http://www.atmos-chem-phys.net/8/129/2008/.

Svendby, T. M., Lazaridis, M., and Torseth, K.: Temperature dependent secondary organic aerosol formation from terpenes and aromatics, J. Atmos. Chem., 59, 25-46, 2008.

Textor, C., Schulz, M., Guibert, S., Kinne, S., Balkanski, Y., Bauer, S., Berntsen, T., Berglen, T., Boucher, O., Chin, M., Dentener, F., Diehl, T., Feichter, J., Fillmore, D., Ginoux, P., Gong, S., Grini, A., Hendricks, J., Horowitz, L., Huang, P., Isaksen, I. S. A., Iversen, T., Kloster, S., Koch, D., Kirkevåg, A., Kristjansson, J. E., Krol, M., Lauer, A., Lamarque, J. F., Liu, X., Montanaro, V., Myhre, G., Penner, J. E., Pitari, G., Reddy, M. S., Seland, Ø., Stier, P., Takemura, T., and Tie, X.: The effect of harmonized emissions on aerosol properties in global models - an AeroCom experiment, Atmos. Chem. Phys., 7, 4489-4501, 2007, http://www.atmos-chem-phys.net/7/4489/2007/.

Tulet, P., Grini, A., Grifin, R., J., and Peticol, S.: ORILAM-SOA: A computationally efficient model for predicting secondary organic aerosols in three-dimensional atmospheric models, J. Geophys Res., 111, D23208, doi:10.1029/2006JD007152, 2006.

Tsigaridis, K. and Kanakidou, M.: Global modelling of secondary organic aerosol in the troposphere: a sensitivity analysis, Atmos. Chem. Phys., 3, 1849-1869, 2003,

http://www.atmos-chem-phys.net/3/1849/2003/.

Vehkamäki, H., Kulmala, M., Napari, I., Lehtinen, K. E. J., Timmreck, C., Noppel, M., and Laaksonen, A.: An improved parameterization for sulphuric acid-water nucleation rates for 
tropospheric and stratospheric conditions, J. Geophys. Res., 107(D22), 4622, doi:10.1029/2002JD2184, 2002.

Vignati, E., Wilson, J., and Stier, P.: M7: An efficient size-resolved aerosol microphysics module for large-scale aerosol transport models, J. Geophys. Res., 109, D22202, doi:10.1029/2003JD004485, 2004.
Volkamer, R., Jimenez, J. L., San Martini, F., Dzepina, K., Zhang, Q., Salcedo, D., Molina, L. T., Worsnop, D. R., and Molina, M. J.: Secondary organic aerosol formation from anthropogenic air pollution: Rapid and higher than expected, Geophys. Res. Lett., 33, L17811, doi:10.1029/2006GL026899, 2006. 